\title{
Organizacijski aspekti regulacijskib tijela za zaštitu tržišnog natjecanja
}

\section{Tadija Kristićn}

\author{
https://doi.org/10.31297/hkju.21.2.4 \\ UDK 366.56(497.5) \\ $35.072 .6(497.5)$ \\ $3.072 .6(497.5)$ \\ 3.078.3(497.5) \\ 35.078.3:366.56 \\ Izvorni znanstveni rad / Original scientific paper \\ Received / primljeno: 22.02.2021. \\ Accepted/prihvaćeno: 22.03.2021.
}

Kriza socijalne države krajem 20. stoljeća razlog je bitnih promjena u odnosu države i građana. Pod utjecajem novoga javnog menadžmenta država se povlači iz pružanja javnih usluga te sve više uključuje privatni sektor. Temeljni zadatak države postaje osigurati funkcioniranje tržišta i ostvariti javni interes regulacijom, što zahtijeva osnivanje regulacijskih tijela, najčešće u obliku agencija. Protekom vremena u javnosti je stvoren često negativan, pomalo i mističan stav prema agencijama. Reforma javne uprave sastavni je dio političkog programa svakoga političkog aktera u Republici Hrvatskoj, a glavna su joj meta regulacijske agencije. Cilj je rada na primjeru regulacijskih tijela za tržišno natjecanje europskih zemalja istražiti organizacijske

* Tadija Kristić, Agencija za zaštitu tržišnog natjecanja (Croatian Competition Agency, e-mail: tadija.kristic@aztn.gov.hr). Mišljenja i stavovi izraženi u radu autorova su osobna mišljenja i ne predstavljaju stav institucije u kojoj radi.

ORCID ID: https://orcid.org 0000-0001-7751-9183 
modele i njihove rezultate primjene te dati preporuke za Republiku Hrvatsku. Za svaki od organizacijskih modela analiziran je primjer agencije kroz ustrojstvo, provedbu propisa i personalne aspekte. Za primjer modela A s isključivom nadležnošću u tržišnom natjecanju analizira se portugalsko tijelo za zaštitu tržišnog natjecanja, za model B s dvostrukom nadležnošću analizira se hrvatsko tijelo za zaštitu tržišnog natjecanja te za model C koji osigurava zaštitu tržišnog natjecanja i sektorsku regulaciju analizirano je španjolsko tijelo za zaštitu tržišnog natjecanja.

Ključne riječi: regulacija, regulacijske agencije, organizacijske promjene, organizacijski modeli, zaštita tržišnog natjecanja

\section{Uvod ${ }^{* *}$}

Agencije dominiraju upravnim sustavima nakon krize socijalne države 80-ih godina prošlog stoljeća i predstavljaju razvoj decentralizacije javne uprave. Agencije su upravne organizacije koje su strukturno izdvojene od središnje državne uprave pa se u literaturi nazivaju quangos (quasi-autonomous non-governmental organizations) - kvaziautonomne nevladine organizacije. Izraz non-governmental zapravo znači da su izdvojene iz središnje državne uprave (Musa, 2014, str. 113). Riječ je, dakle, o organizacijama kojima je prenesena vlast uz djelomičnu kontrolu središnje vlasti te se u pravilu financiraju iz državnog proračuna. Razlozi nastanka agencija brojni su, npr. ističe se neodgovarajuća provedba javnih politika kao temelj razvoja izvršnih agencija u Velikoj Britaniji (Manojlović, 2010, str. 963). Sjedinjene Američke Države kolijevka su razvoja nezavisnih regulacijskih agencija. Prva agencija u SAD-u osnovana je 1887. s ciljem regulacije željezničkog prijevoza - Interstate Commerce Commission. Nedugo zatim, točnije 1914., osnovana je Federal Trade Commission, s ciljem zaštite tržišnog natjecanja (Bajakić, 2010, str. 510; 516). Agencije imaju dugu tradiciju u

** This paper received the "Eugen Pusić" Award in the category of best scientific paper written by student awarded by the Institute of Public Administration in Zagreb in 2020. - Radu je 2020. dodijeljena godišnja nagrada „Eugen Pusić“ Instituta za javnu upravu u kategoriji najboljega znanstvenog rada studenta. 
upravnim sustavima, a u procesu agencifikacije 80 -ih godina 20. stoljeća dodatno se revitaliziraju.

U moderno vrijeme tržišno natjecanje sastavni je dio moderne, demokratske države zasnovane na konceptu liberalnog tržišta. Ipak, taj fenomen u Europi nije dugog vijeka, već je nastao 80-ih godina dvadesetog stoljeća kao odgovor na povlačenje države iz pružanja pojedinih usluga liberalizacijom i privatizacijom kao temeljnim instrumentima doktrine novoga javnog menadžmenta (Koprić, 2013, str. 3; Manojlović, 2010, str. 963). Ponajprije zbog tehnološkog napretka, društvo počinje vjerovati da će se pružanje javnih usluga unaprijediti, odnosno biti djelotvornije, ako se u pružanje javnih usluga uključe privatni pružatelji usluga. Tržišno natjecanje viđeno je kao mogućnost izbora koja će anulirati neučinkovitost, promovirati tehnološki napredak i konačno doprinijeti cjelokupnom napretku društva. Nakon završetka postupka liberalizacije ostala je potreba daljnje regulacije kako bi se smanjili negativni učinci tržišta. Općenito gledajući, ti regulatori ostali su u obliku upravnih organizacija agencijskog tipa (Ottow, 2015, str. 23). Osnivaju se tijela za zaštitu tržišnog natjecanja koja nadziru provedbu tržišnog natjecanja te sektorski regulatori koji osiguravaju i potiču tržišno natjecanje u određenim sektorima tržišta. Građani postaju potrošači odnosno korisnici javnih usluga te se posljedično razvijaju i tijela kojima je cilj zaštita prava potrošača. Protekom vremena u javnosti se stvara negativan stav o radu i funkcioniranju agencija, najčešće zbog netransparentnog trošenja proračunskog novca. Sve se više agencija ukida ili spaja s drugim agencijama u sklopu reforme javne uprave. Tako se u hrvatskoj znanstvenoj javnosti 2014. pojavljuje ideja spajanja hrvatskog regulatora za zaštitu tržišnog natjecanja s ostalim sektorskim regulatorima i osnivanje multisektorskog regulatora (Popović, 2014, str. 223). Cilj je ovog rada analizom europskih agencija utvrditi koji se modeli organizacije agencija primjenjuju te koji su dosadašnji rezultati primjene i koje su preporuke za Hrvatsku.

Rad je podijeljen u četiri poglavlja. Nakon uvoda, u drugom poglavlju rada analiziraju se regulacijske agencije u funkciji tržišnog natjecanja. Definiraju se načini na koji se ona provodi i koja su provedbena tijela. Osim tijela za tržišno natjecanje, analiziraju se ciljevi i funkcije sektorskih regulatora i tijela za zaštitu potrošača. Četvrto poglavlje temelji se na provedenom istraživanju regulacijskih tijela za tržišno natjecanje europskih zemalja. Navode se organizacijski modeli, struktura i nadležnosti pojedinih tijela za tržišno natjecanje u Europi. Obrađuje se pitanje naziva tijela za tržišno natjecanje i pripadnost pojedinomu organizacijskom modelu. Metodologija koja se upotrebljava u istraživanju temelji se na izvorima sa službenih 
internetskih stranica analiziranih tijela, godišnjim izvješćima te podacima iz časopisa Global Competition Review - GCR (2019). Provodi se desktop istraživanje i uzima pojedine agencije kao primjere pojedinih modela te uspoređuje njihova obilježja kao što su ustrojstvo, personalni aspekti, provedba propisa i slično. Kao primjer prvog modela analizira se portugalsko tijelo za tržišno natjecanje. Drugi organizacijski model predstavlja tijelo koje ima dvostruku nadležnost u provedbi te se kao primjer uzima hrvatsko tijelo za tržišno natjecanje. Konačno, kao treći model analiza se španjolsko tijelo za tržišno natjecanje u čijoj je nadležnosti i provedba zaštite tržišnog natjecanja i prethodna regulacija pojedinih sektora gospodarstva. $\mathrm{Na}$ kraju toga poglavlja evaluiraju se podaci iz istraživanja te se usporedbom statističkih podataka prema unaprijed utvrđenim kriterijima utvrđuju razlike u modelima i predlaže optimalan model za Republiku Hrvatsku.

\section{Regulacijske agencije kao upravne organizacije u funkciji tržišnog natjecanja}

\subsection{Definicija agencija}

Agencifikacija je fenomen osnivanja velika broja upravnih organizacija agencijskog tipa koji je zahvatio velik broj upravnih sustava krajem 80-ih godina 20. stoljeća. Osim što se osniva velik broj agencija, postojeće agencije osnažuju se i dodjeljuju im se nove nadležnosti. Razlozi agencifikacije temelje se na povlačenju države iz ekonomskih, socijalnih i drugih društveno-političkih sfera pod utjecajem novoga javnog menadžmenta.

Nema univerzalno prihvaćene definicije agencija kao upravnih organizacija. U teorijskoj šumi škola, smjerova i shvaćanja postoje brojni pokušaji konstruiranja i određivanja temeljnog pojma koji se odnosi na organizacije agencijskog tipa. U određivanju definicije agencija najprije se počeo koristiti negativan pristup te su mnogobrojni autori počeli definirati agencije „isključivanjem onih organizacijskih oblika koji se ne smatraju agencijama“ (Musa, 2014, str. 114). Tako se u pravilu agencijama u užem smislu ne smatraju (ibid.):

1. ministarstva i njihove unutarnje organizacijske jedinice

2. državna odnosno javna poduzeća

3. organizacije civilnog sektora

4. ustavom uspostavljena tijela s izrazitim stupnjem autonomije 
5. agencije koje su osnovali lokalni i regionalni nositelji vlasti.

Iz navedenog proizlazi definicija da su agencije upravne „organizacije izdvojene iz sustava državne uprave, formalno odvojene od ministarstava, koje obavljaju poslove na nacionalnoj razini na trajnoj osnovi, u kojima su obično zaposleni javni službenici i financiraju se uglavnom iz državnog proračuna te su podložne propisima javnog prava“ (Musa, 2014, str. 115). Iz navedene definicije proizlaze sljedeća obilježja agencija (ibid., str. 115-116):

1. institucijska neovisnost - strukturna odvojenost od ministarstva i drugih tijela države uprave

2. javnopravni karakter - obavljanje poslova s javnim ovlastima te čije su nadležnosti propisane zakonom

3. radnici su profesionalni i visokospecijalizirani javni službenici, a radni odnosi uređeni su općim radnim zakonodavstvom, uz neke iznimke u kolektivnom pregovaranju

4. nedostatak financijske autonomije - najčešće financiranje iz državnog proračuna

5. autonomija u odlučivanju - o slučajevima, zapošljavanju i trošenju dodijeljenih im financija

6. kontraktualizacija - u smislu postavljanja ciljeva, načina organiziranja rada i provođenja menadžerskih mjera.

Prema tome ,agencija je dakle tip upravne organizacije koji nastaje u okviru procesa upravne (stvarne, funkcionalne) decentralizacije, dodjeljivanjem upravnih poslova od centralne državne uprave strukturno izdvojenim organizacijama s određenim stupnjem autonomije u djelovanju, s odgovornošću za rezultat i ostvarivanje unaprijed određene posebne svrhe" (Musa, 2012, str. 1206).

\subsection{Nezavisne regulacijske agencije}

Nezavisne regulacijske agencije izum su američkoga upravnog sustava i smatraju se začetkom stvaranja četvrtog dijela u diobi vlasti (Musa, 2014, str. 134). Nadzor nad tim agencijama isključivo je na sudovima te izvršna vlast nema nikakve mehanizme nadzora ili su oni minimalni. Jedna od najvažnijih karakteristika nezavisnih agencija leži u autonomiji u odnosu na izvršnu vlast. Nezavisne regulacijske agencije trebale bi imati veći stupanj autonomije od ostalih agencija, a osobito u smislu organizacije, financira- 
nja i upravljanja ljudskim potencijalima. Trebale bi imati i „zaštitu od povratnog utjecaja tržišnih aktera" (Koprić, 2013, str. 8) te bi njihove odluke trebale biti podložne nadzoru sudova.

Autonomija se očituje u nekoliko mehanizama koji se koriste u pravnoj tehnici kako bi se smanjio politički utjecaj na rad nezavisnih regulatora. Prvi su mehanizam odredbe o zabrani utjecaja na rad agencije koje su sastavni dio propisa o osnivanju, unutarnjih pravilnika i etičkih kodeksa agencija. Drugi mehanizam koji se često koristi kod nezavisnih regulacijskih agencija institut je nespojive funkcije. Zaposlenik agencije ne smije biti ni u kakvu poslovnom odnosu ni s jednim drugim gospodarskim subjektom. Osim navedenog, članovi tijela upravljanja u pravilu imaju nespojive dužnosti u smislu obavljanja političkih funkcija. Također, još su jedna mogućnost odredbe o radnom stažu u određenome znanstvenom polju da bi se moglo postati članom tijela upravljanja. Primjerice, u tijelu za tržišno natjecanje članovi kolegijalnih upravljačkih tijela, osim određenih stupnjeva obrazovanja, moraju imati i potrebnu dužinu radnog staža u tržišnom natjecanju, katkad i više od 10 godina. ${ }^{1}$ Osnovni je izazov agencijskog modela javne uprave osiguranje optimalnog stupnja autonomije uz funkcioniranje sustava kontrole. Uz svakako potrebnu razinu autonomije u navedenim poslovima, treba i jačati nadzor nad radom agencija. Kvalitetnim pravnim (procedure, upravni postupak, sudska kontrola uprave), financijskim (revizije), političkim i demokratskim (transparentnost, godišnja izvješća, stručnost, profesionalizacija) nadzorom mogu se staviti u omjer autonomija i nadzor, što je temelj agencijskog modela (Koprić et al., 2014, str. 204).

Poslovi koje nezavisne regulacijske agencije obavljaju jesu regulacija donošenjem odluka u pojedinim postupcima, regulacija preko općenormativnih akata, nadzor nad provedbom propisa, regulacija profesija, zaštita potrošača, „presuđivanje u sporovima među pružateljima usluga od općeg interesa i u sporovima između pružatelja i potrošača" (Koprić, 2013, str. 9). Prema Musa et al. (2020, str. 7) te poslove možemo podijeliti u tri skupine:

1. regulacija - oblikovanje zadanih ciljeva, utvrđivanje pravnih pravila i postavljanje standarda

${ }^{1}$ Npr. u čl. 28. Zakona o zaštiti tržišnog natjecanja, NN 79/09, 80/13, propisano je da je za člana Vijeća potrebno 10 godina rada u struci i visoko formalno obrazovanje u znanstvenom polju prava ili ekonomije. 
2. odlučivanje - primjena pravila na konkretne slučajeve, utjecanje na ponašanje pružatelja usluga i korisnika, poticaji i sankcije

3. nadzor - prikupljanje informacija i praćenje standarda u sektoru, inspekcija i evaluacija.

Prednosti i nedostaci specifični za nezavisne regulacijske agencije dosta su česta tema u literaturi. Negativan utjecaj na trodiobu vlasti zbog kvazisudskih ovlasti koje ostvaruju, nedovoljna politička neovisnost, nedovoljan stupanj odgovornosti za svoje rezultate i agencijsko zarobljavanje ${ }^{2}$ od velikih kompanija smatraju se nedostacima. Kao prednosti osnivanja nezavisnih regulacijskih agencija navode se konstantno odbijanje političkog utjecaja, profesionalizacija kadrova, specijaliziranija regulacija, bolja kontrola pružanja usluga od općeg interesa, jačanje tržišnog natjecanja i zaštita prava potrošača (Koprić et al., 2014, str. 204).

U RH potrebno je zadovoljiti sljedeće kriterije da bi se pravna osoba smatrala nezavisnom regulacijskom agencijom (Staničić, 2017, str. 65):

- da je riječ o pravnoj osobi s javnim ovlastima izvan sustava državne uprave

- da ima ovlast donošenja podzakonskih propisa i vođenja pojedinačnih upravnih postupaka

- da protiv pojedinačne odluke regulacijske agencije žalba nije dopuštena

- da su osnovane zakonom

- da za svoj rad odgovaraju zakonodavnoj vlasti.

Trenutačno u RH navedene kriterije zadovoljava pet tijela: Agencija za zaštitu tržišnog natjecanja (dalje u tekstu: AZTN), Agencija za elektroničke medije (dalje u tekstu: AEM), Hrvatska agencija za nadzor financijskih usluga (dalje u tekstu: HANFA), Hrvatska energetska regulatorna agencija (dalje u tekstu: HERA) i Hrvatska regulatorna agencija za mrežne djelatnosti (dalje u tekstu: HAKOM). U RH osnovane su i druge agencije, ali jedino se nabrojene mogu smatrati nezavisnim regulacijskim agencijama (Staničić, 2017, str. 65). Musa (2014, str. 492) tu uključuje i dva dodatna tzv. kvaziregulatora iz negospodarskih javnih službi - Agenciju za lijekove

2 Agencijsko zarobljavanje (agency capture) termin je koji opisuje mogućnost utjecaja na donošenje određenih odluka korporacija koje regulira određena nezavisna regulacijska agencija. Jedan je od glavnih razloga mogućnost prelaska zaposlenika iz regulacijskih agencija u korporacije. 
i medicinske proizvode (dalje u tekstu: HALMED) i Agenciju za znanost i visoko obrazovanje (dalje u tekstu: AZVO). ${ }^{3}$

Regulacijske agencije za tržišno natjecanje. Regulacija tržišnog natjecanja u današnjem obliku nastala je krajem 20. stoljeća u sklopu doktrine novoga javnog menadžmenta. Regulacija tržišnog natjecanja ostvaruje se korištenjem s nekoliko regulacijskih instrumenata (Mecanović \& Novosel, 2012, str. 81):

1. pravnim normama - pravo tržišnog natjecanja - propisi o tržišnom natjecanju, trgovini, propisi koji uređuju pitanja trgovačkih društava, zakoni o pojedinim državnim agencijama, financijskim uslugama, propisi o lokalnoj i regionalnoj samoupravi i njihovim nadležnostima u statusnim i drugim pitanjima iz njihove nadležnosti, propisi o trgovačkim poslovima i uključivanje u profesionalna udruženja

2. procesom europeizacije - velik dio članica Europske unije imao je pravo tržišnog natjecanja kao pristupno poglavlje za članstvo u Europskoj uniji, što pokazuje da je tržišno natjecanje jedna od temeljnih politika Europske unije

3. aktivnošću i sudjelovanjem u međunarodnim organizacijama OECD, Svjetska banka, Međunarodni monetarni fond

4. odlukama nacionalnih regulatora u pojedinačnim postupcima.

Regulacija tržišnog natjecanja propisima započinje zakonskim putem, odnosno organizacijskim propisima kojima se definira način na koji će se regulacija provoditi, tim se propisima osnivaju tijela koja će obavljati nadzor nad svim adresatima propisa i koje će ostale poslove obavljati. Onoga trenutka kada regulacija propisima postigne visoku razinu uređenosti i sistematičnosti, možemo govoriti o razvoju nove grane prava. Kada govorimo o pravu tržišnog natjecanja, možemo reći da se sastoji od pravnih normi kojima je cilj osiguranje ,jednakih uvjeta na tržištu za sve poduzetnike, postavljanje jasnih pravila funkcioniranja te ograničavanje slobode njihovog djelovanja“" (Butorac Malnar, Pecotić Kaufman \& Petrović, 2013, str. 3). Pravo tržišnog natjecanja u užem smislu nastaje radi kontrole triju oblika djelovanja koji mogu naštetiti tržišnom natjecanju: karteli ili zabranjeni sporazumi, zlouporabe vladajućeg položaja i koncentracije (ibid., str. 4).

3 „Javne službe ili službe od općeg interesa klasificiraju se na komercijalne (gospodarske, tržišne) i nekomercijalne (negospodarske, netržišne). Takvo shvaćanje javnih službi ponajprije uzima u obzir djelovanje prema tržišnim zakonitostima, a na njegovo oblikovanje značajno je utjecala praksa Suda EU koji se kao temeljnim kriterijem razlikovanja koristio kriterijem funkcionirajućeg tržišnog mehanizma." (Koprić et al., 2014, str. 219). 
Regulaciju tržišnog natjecanja ne provode isključivo tijela za tržišno natjecanje. Velik broj upravih organizacija u svojem djelovanju potiče tržišno natjecanje. Sektorski regulatori u određenim područjima postavljaju „pravila igre“ (Mecanović \& Novosel, 2012, str. 81), dok tijela za zaštitu potrošača promiču interese potrošača nasuprot trgovcima. U nastavku je analiza navedenih tijela kroz razloge osnivanja, funkcije i ciljeve.

Tijela za tržišno natjecanje u pravilu nastaju izdvajanjem policy tržišnog natjecanja iz središnje države uprave i delegiranjem regulacije na samostalna tijela agencijskog tipa. Najčešći su nazivi takvih upravnih organizacija „agencija, komisija ili vijeće“ (Koprić, 2013, str. 9). Riječ je, dakle, o kolegijalnom tijelu koje odlučuje u određenim postupcima, koje gotovo uvijek ima prateću organizaciju i koje provodi istrage i donosi prijedloge odluka. Tijela za tržišno natjecanje imaju ovlasti nadzora provedbe tržišnog natjecanja u svim sektorima gospodarstva. Kao što se kod sektorskih regulatora govori o njihovoj ex ante mogućnosti utjecanja na uspostavu tržišnog natjecanja, ovdje se govori o ex post mogućnosti kontrole poduzetnika na tržištu te sankcioniranju prekršitelja propisa o tržišnom natjecanju. (Popović, 2014, str. 68). „Tijela za tržišno natjecanje teže zaštititi sami proces tržišnog natjecanja, radije nego poduzetnike na tržištu." (Ottow, 2015, str. 30).

Funkcije tijela za tržišno natjecanje možemo podijeliti u tri osnovne skupine: savjetodavnu, „promicajnu“ i provedbenu. Savjetodavna je funkcija (advisory role) mogućnost savjetovanja vlade, drugih državnih tijela, tijela lokalne i regionalne samouprave, javnosti i trgovačkih društava o tržišnom natjecanju (Ottow, 2015, str. 26). Najčešći je oblik savjetovanja davanje stručnih mišljenja na zahtjev navedenih tijela. Tijela za tržišno natjecanje u većini europskih zemalja sudjeluju u postupku izrade zakonodavnih propisa te se od njih očekuje aktivna uloga u predzakonodavnom procesu. U RH u nadležnosti je AZTN-a davanje stručnih mišljenja o ostalim pitanjima koja mogu znatno utjecati na tržišno natjecanje.

Promicanje svijesti o tržišnom natjecanju (advocacy role) jedna je od najvažnijih uloga tijela za tržišno natjecanje koja im daje mogućnost da promiču važnost i dobre primjere tržišnog natjecanja (Ottow, 2015, str. 26). Promicanje svijesti o važnosti tržišnog natjecanja nije namijenjeno samo državnim tijelima preko stručnih mišljenja kako je to navedeno nego obuhvaća i davanje očitovanja u stvarnim, životnim situacijama poduzetnicima, građanima i svim drugim akterima čije djelovanje može biti povreda tržišnog natjecanja. U okviru svojih aktivnosti, tijela za tržišno natjecanje također prate i istražuju određena tržišta. Riječ je o tržištima ili određenim sektorima koji upozoravaju na moguće sprječavanje, ograničavanje ili narušavanje tržišnog natjecanja, a ispituje ih se radi rješavanja tržišnih nedostataka ili netržišnog ponašanja poduzetnika. 
Provedba propisa (enforcement) funkcija je tijela za tržišno natjecanje koja je temeljni razlog njihova osnivanja i razvoja, odnosno vanjski zadatak njihova postanka. „Postoje dva funkcionalna modela provedbe - administrativni i tužiteljski“ (Jenny, 2016, str. 19). Administrativni ili upravni model temelji se na provođenju postupka i donošenju odluke kojom se utvrđuje kršenje propisa tržišnog natjecanja te se u njemu donose i upravne sankcije za počinjenu povredu. Optuženi ima pravo žalbe na nadležnom sudu. Tužiteljski model provedbe organiziran je tako da tijelo za tržišno natjecanje utvrdi moguće postojanje povrede propisa tržišnog natjecanja, provede istražni postupak te da inicijativu za pokretanje postupka podnese na stvarno nadležnom sudu. Sud će odlučiti o postojanju povrede propisa tržišnog natjecanja te izreći sankcije u slučaju da postoje. Uočena je pravna prednost tužiteljskog modela prije svega zato što je nepristranost postupka bolje zaštićena odvajanjem funkcije istrage od funkcije presude u pravosudnom kontekstu nego u upravnom postupku koji je kombiniran u jednoj cjelini. Ipak, velik broj zemalja preuzeo je upravni model jer se na kraju ispostavila nedovoljna specijalizacija sudova u području tržišnog natjecanja (Jenny, 2016, str. 19-20).

Regulacijska tijela za zaštitu potrošača. Zaštita potrošača u vrijeme globalizacije i sveprisutnih proizvoda iz cijeloga svijeta aktivnost je koja prelazi nacionalne okvire i postaje europski, ali i svjetski interes. Glavni je zadatak tijela za zaštitu potrošača provedba nacionalnih i europskih propisa kojima je cilj zaštita prava i interesa kupaca ispred trgovaca. U prijašnjem dijelu istaknuto je da je jedna od opasnosti tržišta informacijska asimetrija. Ta opasnost daje mogućnost trgovcima da, koristeći se lažnim informiranjem, zavaravaju potrošače. Radi toga se u mnogim modernim državama osnivaju tijela kojima je cilj zaštita potrošača. Takva tijela najčešće se osnivaju u obliku regulacijske agencije ili su sastavni dio ministarstava kao izvršne agencije. Valja naglasiti da nepošteno tržišno natjecanje, odnosno nepoštene poslovne prakse poput lažne promidžbe, zavaravajućeg oglašavanja ili iskorištavanja ugleda drugog trgovca, prodaje zbunjujućih i necertificiranih proizvoda i sl. nisu dio prava tržišnog natjecanja. Pravo tržišnog natjecanja ima obilježja javnog prava, dok je zaštita potrošača privatnopravne naravi. To znači da se postupak protiv poduzetnika koji potiče nepošteno tržišno natjecanje vodi isključivo na inicijativu stranke, tj. potrošača, dok se u slučajevima povrede prava tržišnog natjecanja uključuju i javna tijela. To potvrđuje da je pravo tržišnog natjecanja šire od zaštite potrošača te da je zaštita potrošača samo jedna od uloga tržišnog natjecanja (Butorac Malnar, Pecotić Kaufman \& Petrović, 2013, str. 10). Sektorski regulatori. Sektorski regulatori nezavisne su upravne organizacije agencijskog tipa koje se osnivaju u pravilu u jednom području gospodar- 
stva koje je od izričite važnosti za javni interes te je država odlučila da bi regulacijom tih dijelova gospodarstva bolje uočila potencijalne rizike i lakše njima upravljala. Sektorski regulatori zajedno sudjeluju na tržištu u visokospecijaliziranim sektorima, što od zaposlenika zahtijeva visokospecijalizirano znanje. Pratimo li povijesni razvoj sektorskih regulatora, možemo primijetiti da se sektorski regulatori osnivaju u onim dijelovima gospodarstva koji su prije liberalizacije potpuno bili monopolistički te je uslugu pružao javni pružatelj. Regulacija se najčešće provodi u sektoru telekomunikacija, transporta, energije i financijskih usluga. Prema Ottow (2015, str. 29) ciljevi su i poslovi sektorskih regulatora:

1. zaštita krajnjeg korisnika usluga

2. osiguravanje jednakog pristupa tržištu svim akterima

3. zaštita od zlouporabe vladajućeg položaja

4. promicanje tržišnog natjecanja

5. zaštita zakonitosti

6. zaštita javnog interesa.

Iz navedenog proizlazi vidjeti kako je promicanje tržišnog natjecanja cilj sektorskog regulatora, no ono što čini razliku od tijela za tržišno natjecanje jest ex ante karakter regulacije. Sektorski regulator ima mogućnost utjecaja na tržišno natjecanje propisivanjem određenih normi kojima utječe na broj konkurenata, na kvalitetu pružanja usluga te propisivanje određenih kriterija za mogućnost pružanja usluga (certificiranje, dozvole za rad i sl.). U tom slučaju govorimo o „regulaciji za tržišno natjecanje“ (Popović, 2014, str. 68).

Velik je broj ciljeva koji se žele ostvariti sektorskom regulacijom. Osiguravanje pristupa tržištu svim akterima jedan je od najzahtjevnijih. Već postojeći pružatelji usluga na tržištima u kojima nema puno konkurenata najčešće su u vlasništvu infrastrukture te ne dopuštaju konkurentima pristup ili je za pristup propisana visoka naknada. Regulator zato propisuje cijene i uvjete pristupa određenoj infrastrukturi kako bi pristup bio priuštiv svim natjecateljima (Popović, 2014, str. 97). Zaštita krajnjeg korisnika usluga povezana je sa zaštitom javnog interesa. Regulator osiguravanjem univerzalnosti, kvalitete i pristupačnosti uslugama i određenim proizvodima aktivno sudjeluje u poboljšanju kvalitete života građana. Cilj je sektorskih regulatora zaštita krajnjih korisnika usluga (Ottow, 2015, str. 29). 


\section{Istraživanje organizacijskih aspekata regulacijskih tijela za zaštitu tržišnog natjecanja}

Ne postoji jednoznačan odgovor na pitanje koji je organizacijski oblik bolji jer svaki organizacijski oblik ima svoje prednosti i nedostatke, a optimalno rješenje ovisi o brojnim čimbenicima. Usporedimo li europske zemlje, možemo vidjeti da se pojavljuje više aspekata organizacijskih oblika ili kombinacija sektorskih regulatora, tijela za tržišno natjecanje i tijela za zaštitu potrošača. Nastavak istraživanja temelji se na organizaciji tijela za tržišno natjecanje i njihovim nadležnostima u odnosu na sektorske regulatore i tijela za zaštitu potrošača. Analizom dobivenih rezultata utvrđeni su sljedeći modeli:

- MODEL A - tijelo za tržišno natjecanje ima isključivo nadležnost za provođenje propisa tržišnog natjecanja. Zaštita potrošača u nadležnosti je drugog tijela, a regulacija pojedinih tržišta u nadležnosti je većeg broja sektorskih regulatora

- MODEL B - tijelo za tržišno natjecanje nadležno je, uz zaštitu tržišnog natjecanja, i za zaštitu potrošača i/ili ostale nadležnosti, dok je regulacija tržišta prepuštena sektorskim regulatorima

- MODEL C - u nadležnosti je tijela za tržišno natjecanje zaštita tržišnog natjecanja, zaštita potrošača i/ili ostale nadležnosti i sektorska regulacija.

Istraživanje je provedeno u svim europskim zemljama ${ }^{4}$ na način da su se provjerile nadležnosti tijela za tržišno natjecanje. Korištena je metoda istraživanja pregledom internetskih stranica svih tijela u svim europskim zemljama. U Tablici 1. prikazana su tijela za tržišno natjecanje Europe u pripadajućem organizacijskom modelu u kojem se pojavljuju. Od ukupno promatranih 45 država, u 16 je država zaštita tržišnog natjecanja jedina nadležnost nacionalnih tijela za tržišno natjecanje (model A), u 21 državi nacionalni regulatori tržišnog natjecanja obavljaju dodatne aktivnosti poput zaštite potrošača, dodjele državnih potpora, regulacije profesija, zaštite od nepoštenih trgovačkih praksi (model B) te u osam država nacionalna tijela za tržišno natjecanje osim zaštite tržišnog natjecanja imaju i regulacijske ovlasti u pojedinim sektorima gospodarstva (model C).

${ }^{4}$ Istraživanje je provedeno prema popisu država članica Vijeća Europe, dostupno na http://www.mvep.hr/hr/vanjska-politika/multilateralni-odnosi-staro-ijvhj/vijece-europe(ve)-staro/popis-clanica-vijeca-europe/, pristup 20.8.2020. Iz popisa su isključene države Kneževina Monako i Republika San Marino jer nemaju institucionaliziranu zaštitu tržišnog natjecanja. 


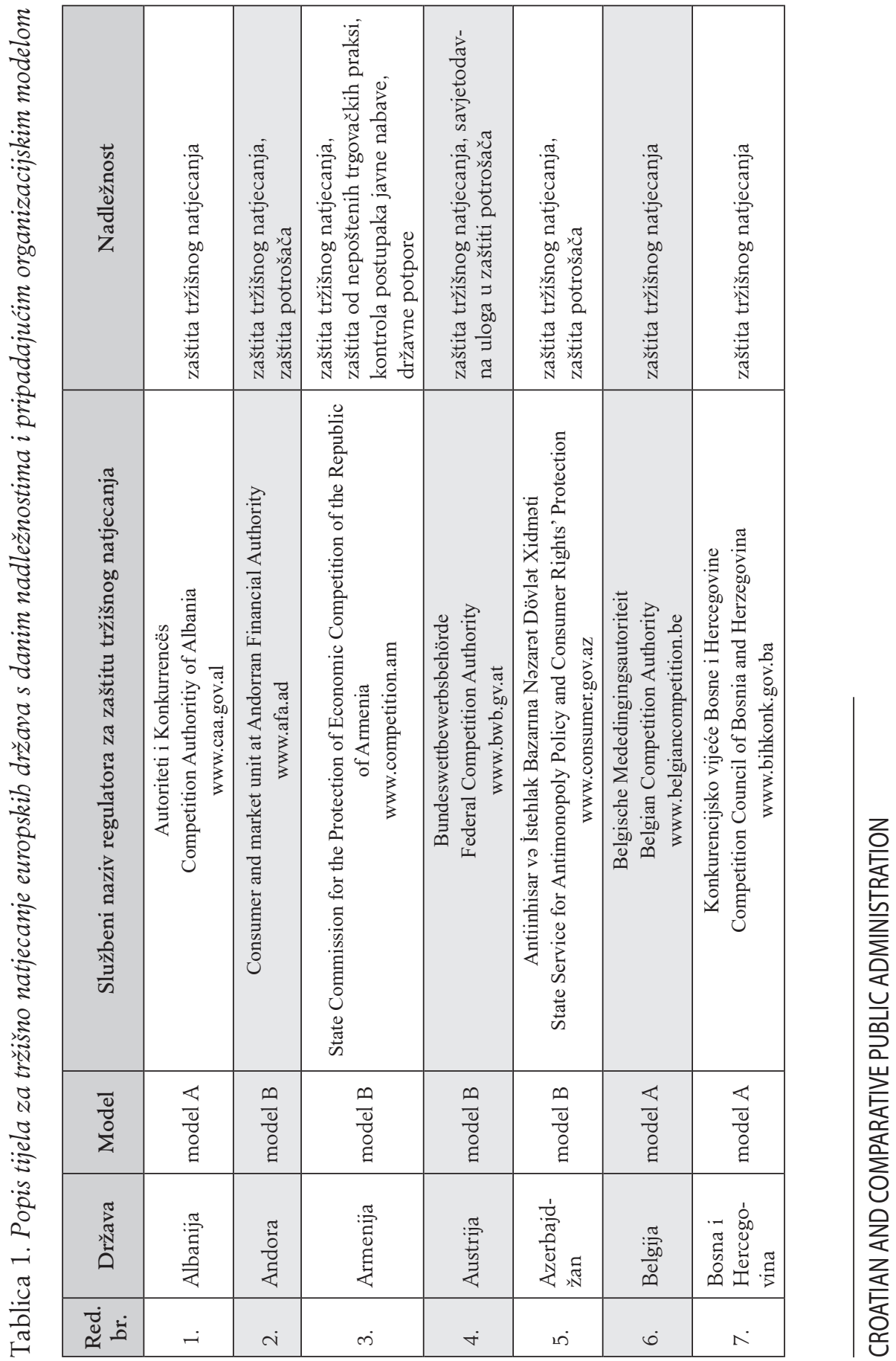




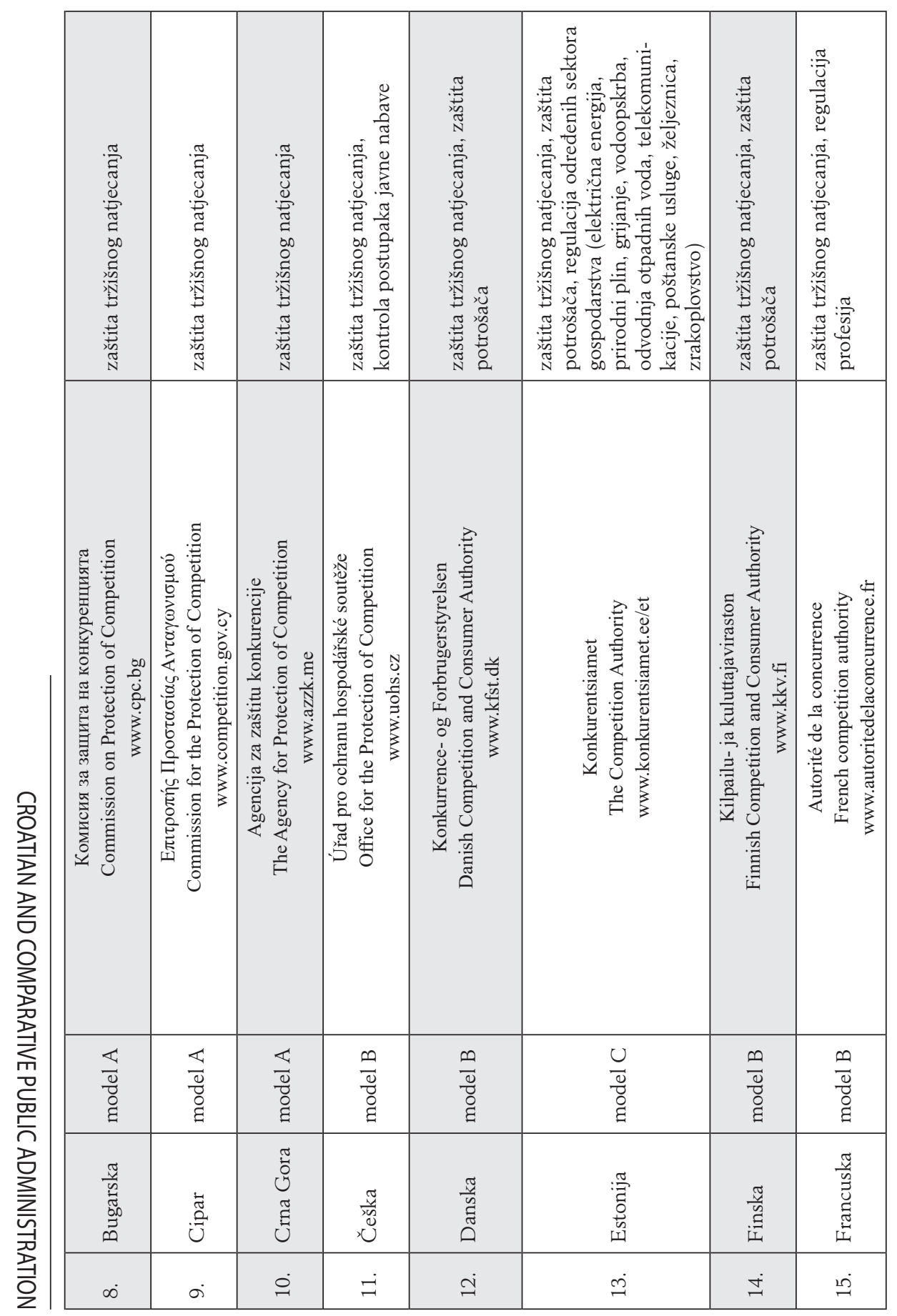




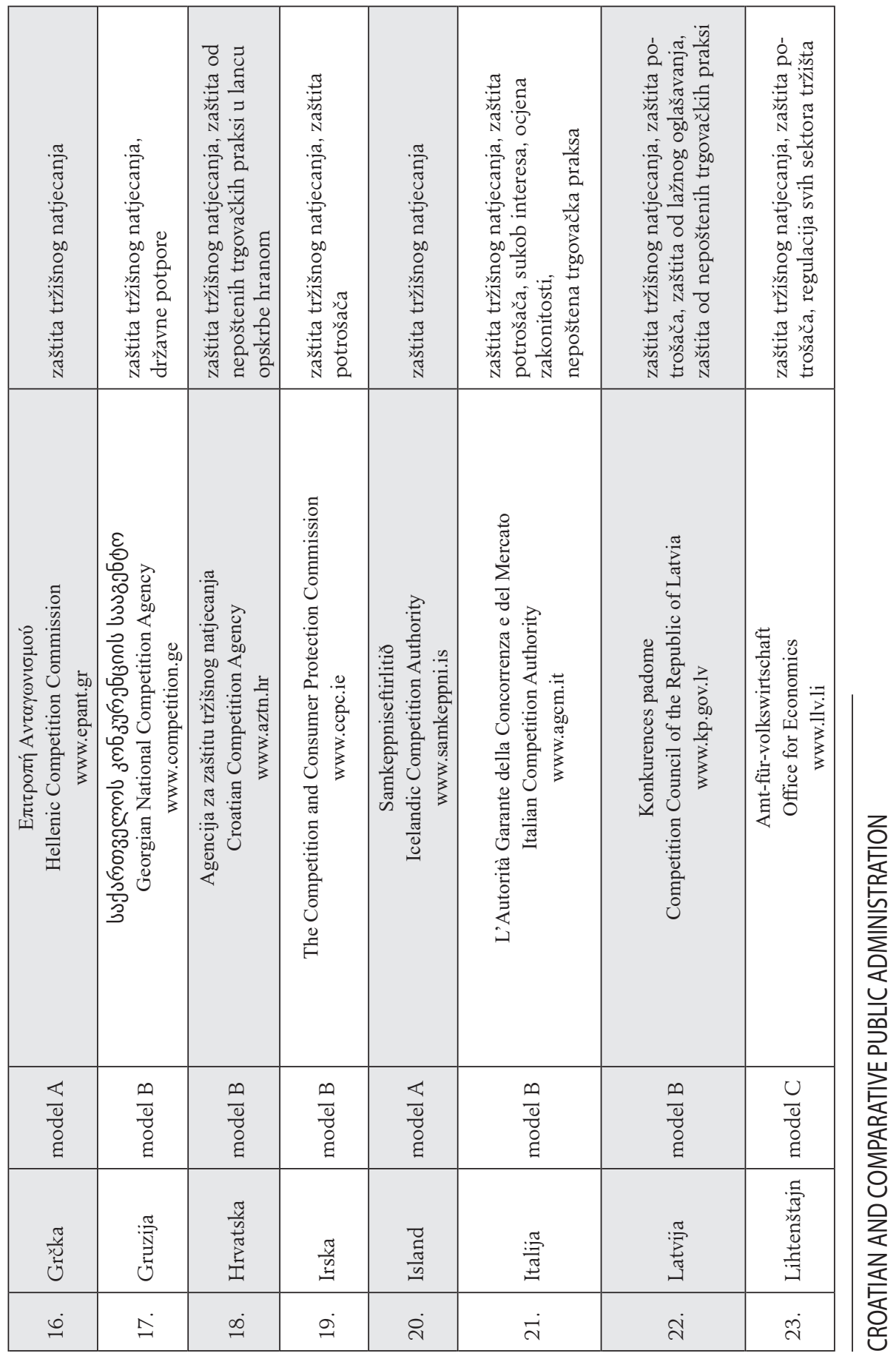




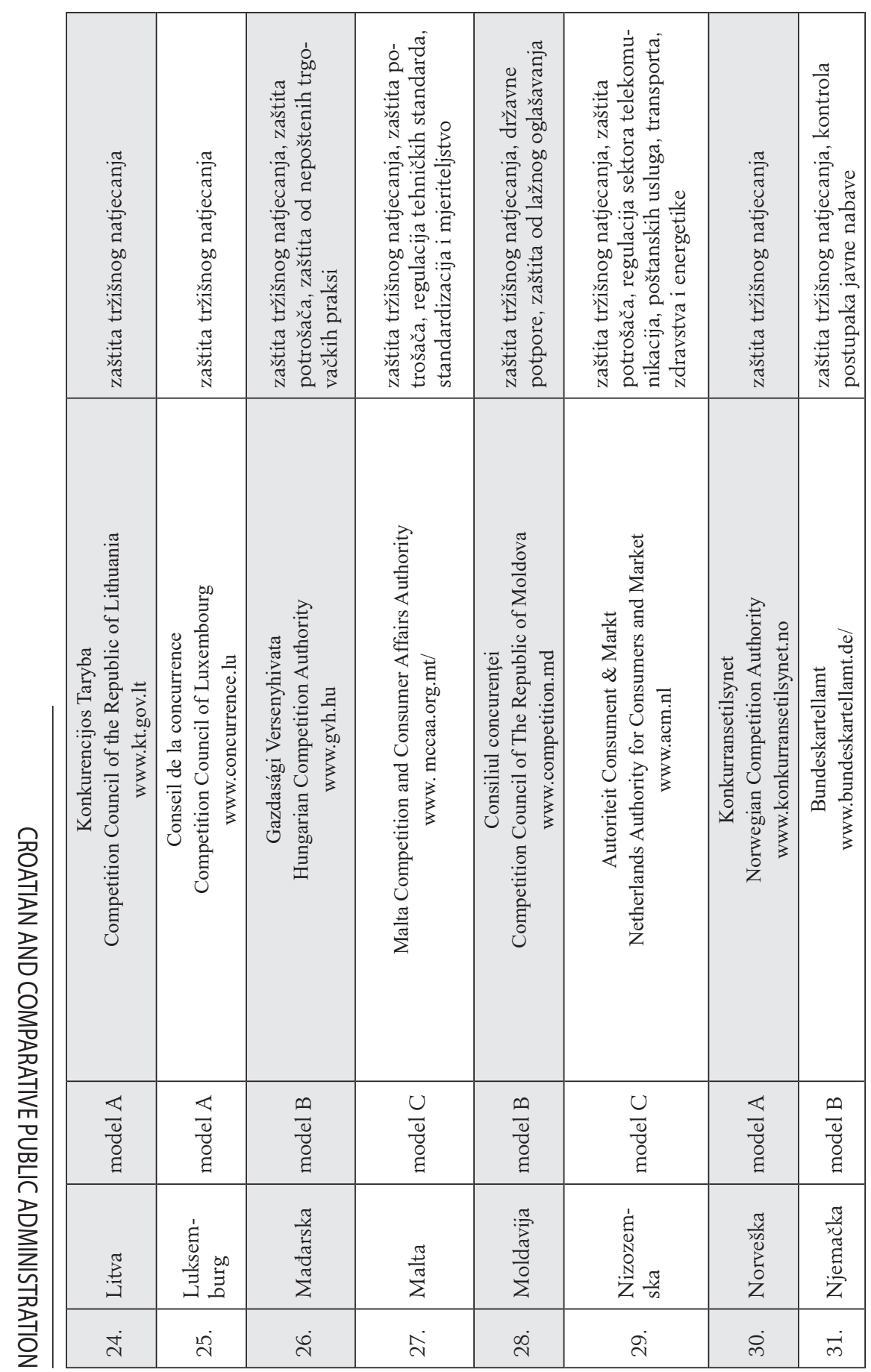




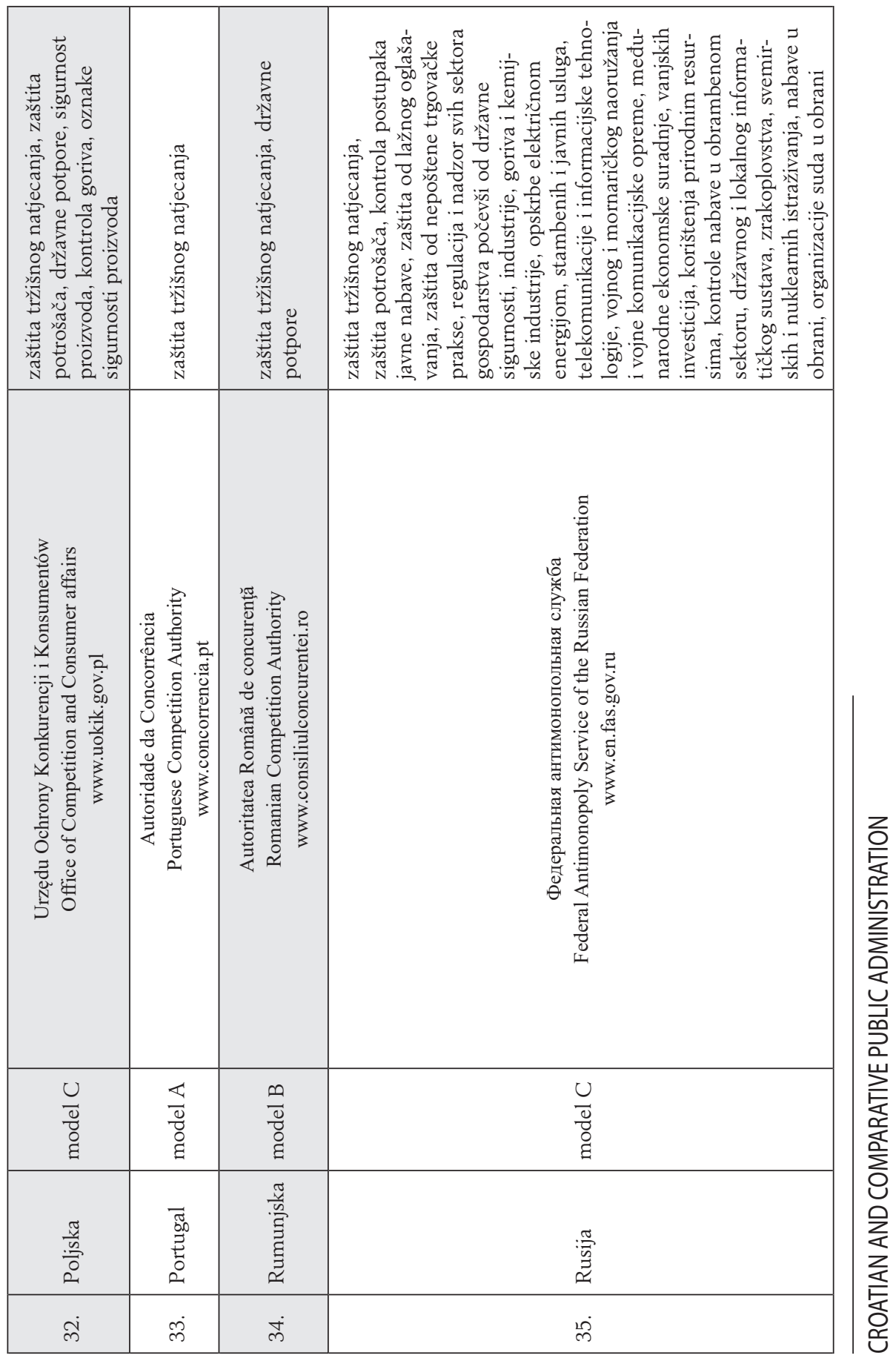




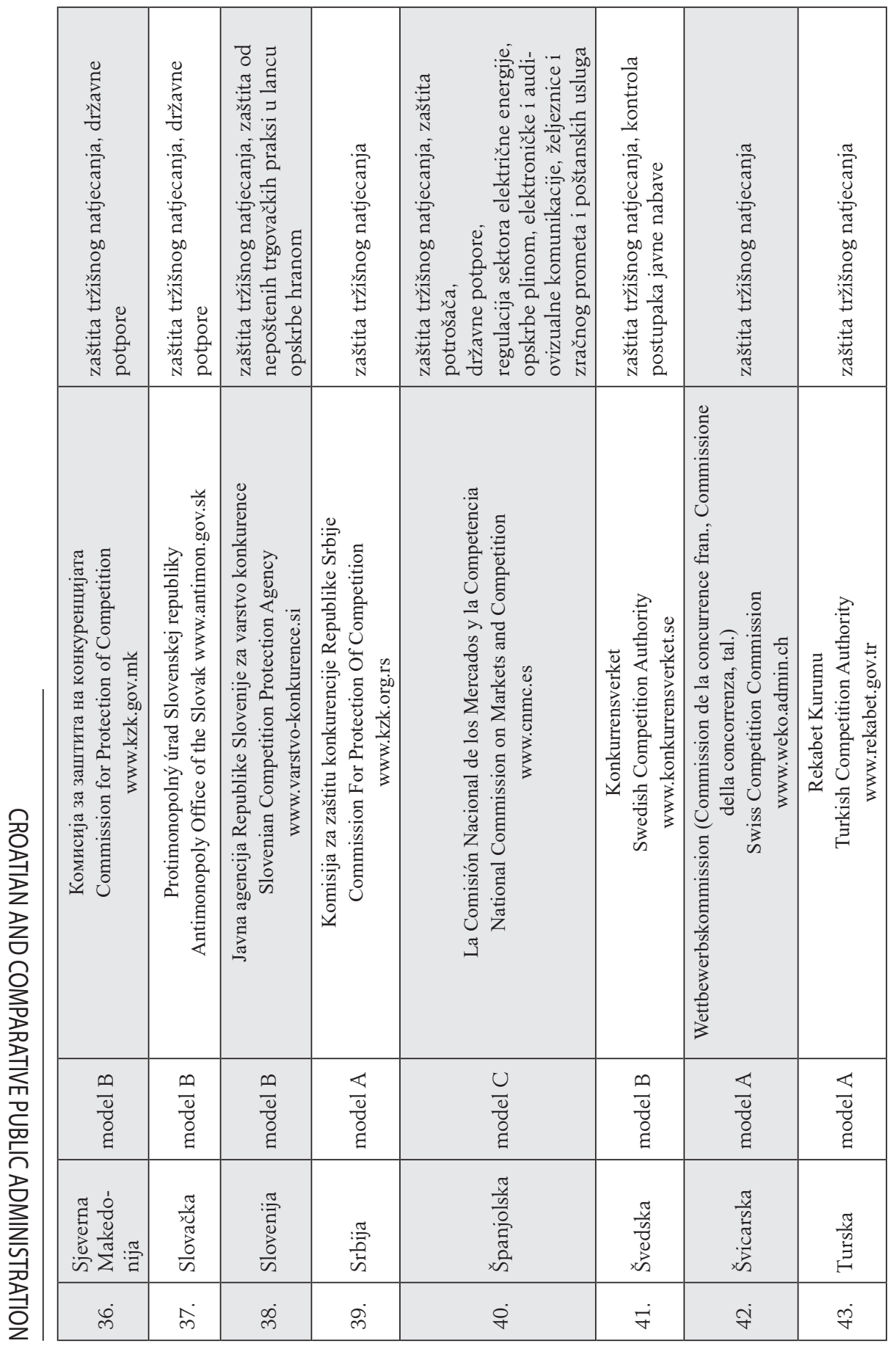




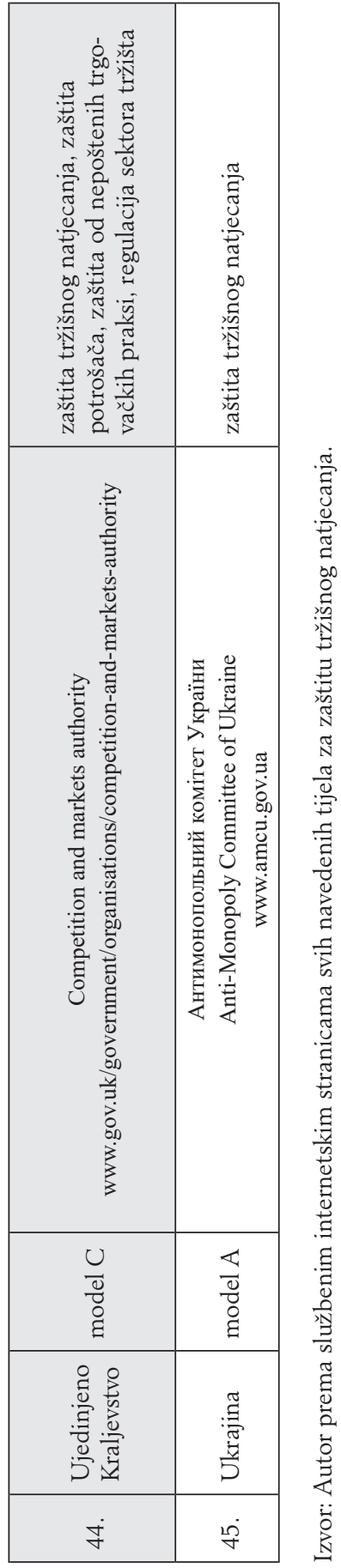


Modeli su podijeljeni prema odnosu tijela za zaštitu tržišnog natjecanja naspram tijela za zaštitu potrošača i sektorskih regulatora u pojedinoj državi. Podaci iz Tablice 2. pokazuju da nema povezanosti između organizacijskog modela i modela javne uprave u promatranim državama. Primjerice, francusko tijelo za zaštitu tržišnog natjecanja ima više nadležnosti, dok portugalsko ima jednu, a pripadaju napoleonskom modelu javne uprave. Promatramo li zemlje skandinavskog (nordijskog) modela, primjerice Dansku i Norvešku, vidljiva je razlika u modelima i nadležnostima. Isto tako, nemoguće je povezati s modelom javne uprave spajanja agencija koja su se ostvarila u određenim upravnim sustavima. Spajanja agencija ostvarena su u Estoniji, Lihtenštajnu, Malti, Nizozemskoj, Poljskoj, Rusiji, Španjolskoj i Ujedinjenom Kraljevstvu. Nabrojene države pripadaju različitim upravnim modelima te ne postoji korelacija modela javne uprave i organizacijskog modela tijela za zaštitu tržišnog natjecanja.

Tablica 2. Popis država s pripadajućim organizacijskim modelima

\begin{tabular}{|c|c|c|c|}
\hline $\begin{array}{c}\text { Redni } \\
\text { broj }\end{array}$ & Model A & Model B & Model C \\
\hline 1. & Albanija & Andora & Estonija \\
\hline 2. & Belgija & Armenija & Lihtenštajn \\
\hline 3. & Bosna i Hercegovina & Austrija & Malta \\
\hline 4. & Bugarska & Azerbajdžan & Nizozemska \\
\hline 5. & Cipar & Češka & Poljska \\
\hline 6. & Crna Gora & Danska & Rusija \\
\hline 7. & Grčka & Finska & Španjolska \\
\hline 8. & Island & Francuska & Ujedinjeno Kraljevstvo \\
\hline 9. & Litva & Gruzija & - \\
\hline 10. & Luksemburg & Hrvatska & - \\
\hline 11. & Norveška & Irska & - \\
\hline 12. & Portugal & Italija & - \\
\hline 13. & Srbija & Latvija & - \\
\hline 14. & Švicarska & Mađarska & - \\
\hline 15. & Turska & Moldavija & - \\
\hline 16. & Ukrajina & Njemačka & - \\
\hline 17. & - & Sjeverna Makedonija & - \\
\hline
\end{tabular}




\begin{tabular}{|c|c|c|c|}
\hline 18. & - & Slovačka & - \\
\hline 19. & - & Slovenija & - \\
\hline 20. & - & Švedska & - \\
\hline 21. & - & Rumunjska & - \\
\hline
\end{tabular}

Izvor: Autor prema službenim internetskim stranicama svih navedenih tijela za zaštitu tržišnog natjecanja.

U nastavku rada analizirat će se rad agencija koje će predstavljati svaki od utvrđenih modela. Tako će se za primjer modela A analizirati Agencija za zaštitu tržišnog natjecanja u Portugalu, za primjer modela B hrvatska Agencija za zaštitu tržišnog natjecanja te za primjer modela $C$ španjolska Komisija za tržište i tržišno natjecanje. Razlog je odabira Španjolske i Portugala dokazivanje tvrdnje da susjedne zemlje koje pripadaju istim upravnim modelima mogu imati različite modele tržišnog natjecanja unatoč minimalnim vanjskim različitim faktorima između njih. Najprije će se dati kratak pregled i pravna osnova za djelovanje svakog od navedenih tijela, prikazati organizacijska struktura i podaci o zaposlenima. U dijelu provedbe analizirat će se trajanje postupaka te uloga u promicanju tržišnog natjecanja. Cilj je utvrditi razlike u organizacijskoj strukturi, profesionalizaciji zaposlenih te utječu li te razlike na provedbu i učinkovitost. Radi lakšeg pristupa informacijama detaljnije će biti prikazan rad i ustrojstvo hrvatske Agencije za zaštitu tržišnog natjecanja.

\subsection{Agencija za zaštitu tržišnog natjecanja, Portugal (model A)}

Model A regulatora tržišnog natjecanja karakterizira postojanje tijela za tržišno natjecanje s isključivom nadležnošću iz zaštite tržišnog natjecanja. Tako je model A zastupljen u 16 zemalja: Albaniji, Belgiji, Bosni i Hercegovini, Bugarskoj, Cipru, Crnoj Gori, Grčkoj, Islandu, Litvi, Luksemburgu, Norveškoj, Portugalu, Srbiji, Švicarskoj, Turskoj i Ukrajini.

Klasičan je primjer modela A portugalska Agencija za zaštitu tržišnog natjecanja ili na portugalskom Autoridade da Concorrincia (dalje u tekstu: AdC), pravna osoba s javnim ovlastima kojoj je dana nadležnost iz zaštite tržišnog natjecanja. Osnovana je 2003. godine te je neovisna i financijski autonomna upravna organizacija. 
1. Organizacijska struktura AdC-a. AdC ima sljedeće glavne ustrojstvene jedinice:

- Vijeće kao tijelo upravljanja

- Glavnu upravu za istrage kao temeljnu strukturu koja obavlja poslove stavljene u nadležnost AdC-a

- Glavno tajništvo, koje se brine za interno funkcioniranje AdC-a

- Ured za analizu i praćenje tržišta

- Posebnu jedinicu za praćenje politika

- Kabinet predsjednika Vijeća

- revizora kao nadzorno tijelo.

AdC-om upravlja Vijeće od triju članova na čelu s predsjednikom. Članove Vijeća imenuje vlada. U sklopu su Vijeća i stručna služba i ostalo administrativno osoblje vezano za rad i donošenje odluka. AdC ima zastupljen upravni model provedbe. Tijelo revizije drugo je ključno tijelo koje ima zadaću kontrolirati financijsku ispravnost rada AdC-a. Odabrani su iz registra revizora i u odlukama je potrebna suglasnost portugalskog ministarstva za gospodarstvo i financije. Unutarnje ustrojstvo AdC-a dijeli se na Glavnu upravu za istrage, pod kojom je Odjel za ocjenu koncentracija, Odjel za pravna pitanja, Odjel za narušavanje tržišnog natjecanja koji je podijeljen na Jedinicu za zabranjene sporazume i Jedinicu za ostala narušavanja. Druga je uprava Glavno tajništvo koje sadržava financijske poslove, upravljanje ljudskim potencijalima i informacijske tehnologije $\mathrm{i}$ komunikaciju. U Kabinetu predsjednika je Jedinica za međunarodne odnose. Posebno mjesto iznad Glavne uprave za istrage i Glavnog tajništva ima Specijalna jedinica za tržišno natjecanje u javnim politikama. ${ }^{5}$

2. Podaci o zaposlenima. U Tablici 3. prikazano je da su 2018. u AdC-u bila 74 zaposlenika, od toga je na poslovima tržišnog natjecanja radilo 66 zaposlenih, što čini 89 \%. Od ukupnog broja zaposlenih, bilo je 58 \% žena i 90 \% visokoobrazovanih. Raspored radnih mjesta takav je da 14 zaposlenih radi na ocjeni koncentracija, 27 na ocjeni zabranjenih sporazuma i zlouporaba vladajućeg položaja te 25 na ostalim poslovima u promicanju tržišnog natjecanja i općim poslovima. Od ukupnog proračuna AdC-a od oko 9 milijuna eura, oko $75 \%$ odlazi na plaće zaposlenih.

${ }^{5}$ Organizacijsku strukturu AdC-a vidjeti na: http://www.concorrencia.pt/vEN/ A_AdC/Organization/Pages/Organization.aspx. 
Tablica 3. Podaci o zaposlenima u AdC-u u 2018.

\begin{tabular}{|l|l|}
\hline ukupan broj zaposlenih & 74 \\
\hline ukupan broj novozaposlenih & 9 \\
\hline ukupan broj odljeva zaposlenih & 2 \\
\hline broj zaposlenih na poslovima tržišnog natjecanja & 66 \\
\hline odnos broja žena naspram broja muškaraca & $58 \% / 42 \%$ \\
\hline prosječna starost zaposlenika & 42 godine \\
\hline postotak visokoobrazovanih & $90 \%$ \\
\hline postotak pravnika & $52 \%$ \\
\hline postotak ekonomista & $38 \%$ \\
\hline ukupan broj zaposlenika sa završenim stupnjem doktora znanosti & 8 \\
\hline broj zaposlenika koji rade na ocjeni koncentracija & 27 \\
\hline broj zaposlenika koji rade na utvrđivanju zlouporaba & 13 \\
\hline broj zaposlenika koji rade na utvrđivanju zabranjenih sporazuma & 12 \\
\hline ukupan proračun & $9.017 .251 €$ \\
\hline izdvajanja za plaće & $75 \%$ \\
\hline
\end{tabular}

Izvor: Autor prema GCR-u (2019, str. 153).

Provedba propisa. Iz Tablice 4. vidljivo je da je AdC proveo 46 postupaka ocjene koncentracija, što se prosječno rješava 199 dana. U dijelu ocjena zabranjenih sporazuma imali su jednu prijavu pokajnika, proveli su četiri nenajavljene pretrage i okončali četiri postupka. Izrekli su 12,4 milijuna eura upravnih sankcija. Trajanje je postupka 675 dana. U dijelu zlouporaba vladajućeg položaja okončali su jedan postupak i nisu izrekli upravne sankcije. Prosječno je trajanje postupka 1.238 dana. AdC ima iznimno visok uspjeh što se tiče nadzora zakonitosti donesenih odluka. Prema dostupnim podacima, 95 \% odluka potvrđeno je na sudovima. Najčešći su razlozi ukidanja presuda procesna pitanja, radi prava uvida u spis, nezakonita pristupa podacima i u vezi s ostalim procesnim pravima (GCR, 2019, str. 155).

Tablica 4. Analiza provedbe u AdC-u u 2018.

\begin{tabular}{|c|l|l|}
\hline \multicolumn{2}{|l|}{ Provedba - ocjena dopuštenosti koncentracija } & \\
\hline & broj zatvorenih predmeta & 46 \\
\hline
\end{tabular}




\begin{tabular}{|l|l|l|}
\hline \multicolumn{2}{|l|}{ prosječan broj dana za rješavanje } & 199 \\
\hline \multicolumn{2}{|l|}{ Provedba - ocjena zabranjenih sporazuma } & \\
\hline & broj zatvorenih predmeta & 4 \\
\hline & nenajavljene pretrage & 4 \\
\hline & prijave pokajnika & 1 \\
\hline & izrečeno sankcija & $12.400 .000 €$ \\
\hline & prosječan broj dana trajanja postupka & 675 \\
\hline Provedba - utvrđivanje zlouporaba vladajućeg položaja & \\
\hline & broj zatvorenih predmeta & 1 \\
\hline & izrečeno upravnih sankcija & 0 \\
\hline & prosječan broj dana trajanja postupka & 1.238 \\
\hline
\end{tabular}

Izvor: Autor prema GCR-u (2019, str. 153-156).

Promicanje svijesti o tržišnom natjecanju. U dijelu promicanja svijesti o tržišnom natjecanju (tzv. advocacy) AdC ima uključena dva odjela. Jedan je za izradu mišljenja o javnim politikama u Specijalnoj jedinici za tržišno natjecanje u javnim politikama, dok je drugi odjel, koji također radi na promicanju svijesti o važnosti tržišnog natjecanja, Jedinica za međunarodnu suradnju u sklopu Kabineta predsjednika. Godine 2018. AdC je izdao više od 750 preporuka koje su inicirali poduzetnici, građani i tijela javnih vlasti ili na svoju inicijativu. Sudjelovali su u četirima radnim skupinama za izradu propisa te izdali 30 mišljenja na prijedloge propisa. Prema procjenama, izdane preporuke i mišljenja imali su utjecaj na više od 380 milijuna eura građana i poduzetnika, a osobito u sektoru transporta i regulaciji profesija.

\subsection{Agencija za zaštitu tržišnog natjecanja, Hrvatska (model B)}

Provedeno istraživanje nadležnosti tijela za tržišno natjecanje u europskim zemljama dokazalo je da u 21 zemlji prevladava model B. Uključujući RH, riječ je još o Andori, Armeniji, Austriji, Azerbajdžanu, Češkoj, Danskoj, Finskoj, Francuskoj, Gruziji, Irskoj, Italiji, Latviji, Mađarskoj, Moldaviji, Njemačkoj, Sjevernoj Makedoniji, Slovačkoj, Sloveniji, Švedskoj i Rumunjskoj. Najčešća je druga nadležnost zaštita potrošača, zatim 
državne potpore, kontrola postupaka javne nabave i zaštita od nepoštenih trgovačkih praksi.

AZTN je pravna osoba s javnim ovlastima sui generis osnovana 1995. odlukom Hrvatskog sabora, a započela je rad 1997. s nadležnošću iz zaštite tržišnog natjecanja. Koncem 2017. godine, osim dotadašnje zaštite tržišnog natjecanja, u nadležnost joj je dana i zaštita od nepoštenih trgovačkih praksi u lancu opskrbe hranom. Zakon o zabrani nepoštenih trgovačkih praksi u lancu opskrbe hranom ${ }^{6}$ (dalje u tekstu: ZNTP) stupio je na snagu 7. 12. 2017., a u punoj je primjeni od 1. 4. 2018.

Trenutačno vrijedi Zakon o zaštiti tržišnog natjecanja (dalje u tekstu: ZZTN) donesen 2009. godine, a stupio je na snagu 1. listopada 2010. godine. Tim je zakonom tržišno natjecanje RH potpuno usklađeno s pravom Europske unije. Potreba za donošenjem novog propisa bila je u tome što je nadzor na aktima AZTN-a bio na prekršajnim sudovima koji nisu pravodobno rješavali predmete: „Međutim, prekršajni sudovi pri izricanju kazni, postupajući po optužnom prijedlogu AZTN-a, ulaze u meritum odluke AZTN-a. Dakle, prekršajni sud ne utvrđuje samo visinu kazne, već i ocjenjuje je li došlo do povrede propisa o konkurenciji, iako je to AZTN utvrdio u okviru svoje nadležnosti, donio o tome rješenje i na temelju njega sastavio optužni prijedlog za prekršajni sud. Tako prekršajni sudovi, via facti, u praksi postupaju kao svojevrsna "drugostupanjska“ tijela i u stvari kontroliraju zakonitost odluka AZTN-a." (Cerovac, 2009, str. 4). Osim zakonskih propisa, velik broj uredbi i ostalih pravnih propisa uređuje pitanje zaštite tržišnog natjecanja. ${ }^{7}$

3, Organizacijska struktura AZTN-a. AZTN je pravna osoba s javnim ovlastima pod čiju nadležnost ulazi provedba postupaka iz zaštite tržišnog natjecanja i provedba zaštite od nepoštenih trgovačkih praksi u lancu opskrbe hranom. Slika 2. „Organigram AZTN-a“ detaljno prikazuje unutarnju strukturu i odnos hijerarhije u AZTN-u. Osnovnu organizacijsku strukturu čine:

- Vijeće za zaštitu tržišnog natjecanja

- dva ureda: Ured vijeća i Ured glavnog ekonomista

- Sektor za opće poslove

- dva sektora za poslove iz nadležnosti: jedan za tržišno natjecanje i jedan za zabranu nepoštenih trgovačkih praksi.

\footnotetext{
${ }^{6}$ Zakon o zabrani nepoštenih trgovačkih praksi u lancu opskrbe hranom, NN 117/17.

${ }^{7}$ Više o pravnom okviru AZTN-a: http://www.aztn.hr/trzisno-natjecanje/pravni-okvir/.
} 
Radom AZTN-a upravlja Vijeće za zaštitu tržišnog natjecanja (dalje u tekstu: Vijeće AZTN-a) koje broji pet članova. Članove Vijeća AZTN-a imenuje Hrvatski sabor na prijedlog Vlade $\mathrm{RH}$ na mandat od pet godina. $\mathrm{Na}$ čelu je Vijeća AZTN-a predsjednik AZTN-a kojeg imenuje Hrvatski sabor na prijedlog Vlade RH iz redova Vijeća AZTN-a.

Organizacija je podijeljena na Sektor za tržišno natjecanje, Sektor za zabranu nepoštenih trgovačkih praksi i Sektor za opće poslove. Unutar Sektora za tržišno natjecanje je Odjel za utvrđivanje zabranjenih sporazuma s pripadajućim Odsjekom za forenziku i informatiku, zatim Odjel za utvrdivanje zlouporaba, Odjel za ocjenu koncentracija, Odjel za legislativu i komparativnu praksu i Odjel za međunarodnu i europsku suradnju. Unutar Sektora za zabranu nepoštenih trgovačkih praksi uspostavljena su dva odjela: Odjel za pravna pitanja utvrđivanja nepoštenih trgovačkih praksi i Odjel za ekonomska pitanja utvrđivanja nepoštenih trgovačkih praksi. Sektor za opće poslove podijeljen je na Odjel za opće poslove, Odjel za financije i računovodstvo i Odjel za komunikacije. Osim navedenih sektora, osnovan je i Ured glavnog ekonomista kao posebna jedinica za istraživanje tržišta i Ured Vijeća za administrativnu podršku Vijeću AZTN-a. ${ }^{8}$ Podaci o zaposlenima. Podaci iz Tablice 5. prikazuju da je AZTN 2018. imao 52 zaposlena uključujući i Vijeće AZTN-a. Izuzmemo li Vijeće AZTN-a, od preostalih 47 zaposlenih njih 42 ili $80 \%$ bilo je direktno uključeno u provedbu propisa iz tržišnog natjecanja i nepoštenih trgovačkih praksi u lancu opskrbe hranom. Tako se ocjenama koncentracija bavilo pet zaposlenika, zlouporabama vladajućeg položaja sedam zaposlenika, zabranjenim sporazumima također sedam zaposlenika, pravnim pitanjima i komparativnom praksom dva zaposlenika, tri zaposlenika radila su u Uredu glavnog ekonomista te u Odjelu za međunarodnu i europsku suradnju tri zaposlenika. Na poslovima utvrđivanja nepoštenih trgovačkih praksi radilo je osam zaposlenih. Preostali su bili zaposleni na tehničkoadministrativnim poslovima AZTN-a. Prosječna je starost zaposlenika 42 godine te je postotak visokoobrazovanih oko $91 \%$. Ukupan je proračun oko 13 milijuna kuna te na plaće zaposlenih odlazi $65 \%$ proračuna, što je okvirno 8,5 milijuna kuna.

${ }^{8}$ Organizacijsku strukturu AZTN-a vidjeti na: http://www.aztn.hr/o-nama/nadleznost-i-ustrojstvo/struktura/. 
Tablica 5. Podaci o zaposlenima u AZTN-u 2018.

\begin{tabular}{|l|l|}
\hline ukupan broj zaposlenih & 52 \\
\hline ukupan broj novozaposlenih & 8 \\
\hline ukupan broj odljeva zaposlenih & 0 \\
\hline broj zaposlenih na poslovima tržišnog natjecanja & 34 \\
\hline broj zaposlenih na poslovima utvrđivanja nepoštenih trgovačkih praksi & 8 \\
\hline odnos broja žena naspram broja muškaraca & $58 \%$ / 42 \% \\
\hline prosječna starost zaposlenika & 42 godine \\
\hline postotak visokoobrazovanih & $91 \%$ \\
\hline postotak pravnika & $42 \%$ \\
\hline postotak ekonomista & $28 \%$ \\
\hline ukupan broj zaposlenika sa završenim stupnjem doktora znanosti & 1 \\
\hline broj zaposlenika koji rade na ocjeni koncentracija & 5 \\
\hline broj zaposlenika koji rade na utvrđivanju zlouporaba & 7 \\
\hline broj zaposlenika koji rade na utvrđivanju zabranjenih sporazuma & 7 \\
\hline ukupan proračun & 13 milijuna kuna \\
\hline izdvajanja za plaće & $65 \%$ \\
\hline
\end{tabular}

Izvor: Autor prema Godišnjem izvješću o radu Agencije za zaštitu tržišnog natjecanja za 2018. godinu.

4. Provedba propisa. U RH postupak provedbe propisa tržišnog natjecanja uređen je ZZTN-om, a utvrđivanje nepoštenih trgovačkih praksi ZNTPom, na način da AZTN pokreće postupak na temelju zahtjeva stranke i po službenoj dužnosti. AZTN je ovlašten zahtijevati sve potrebne podatke i informacije koje smatra potrebnima radi utvrđivanja svih relevantnih činjenica u postupku, i to od poduzetnika na hrvatskom tržištu koji su stranke u postupku, ali i od drugih poduzetnika i osoba koje mogu pridonijeti rješavanju pitanja o sprječavanju, ograničavanju ili narušavanju tržišnog natjecanja, odnosno nepoštenih trgovačkih praksi.

$\mathrm{U}$ analizi provedbe propisa tržišnog natjecanja korišteni su podaci za 2018. godinu uz naznaku na „upravljačku krizu“9 koncem godine. Obra-

${ }^{9}$ Prema podatku iz Godišnjeg izvješća o radu AZTN-a u 2018.: „Jedna od negativnih okolnosti, na koju AZTN nije mogao utjecati, a nepovoljno se odrazila na ukupan broj riješenih predmeta u izvještajnoj godini, je prekid rada Vijeća AZTN-a u razdoblju od 15. studenoga 2018. do 25. siječnja 2019. godine. Naime, dana 15. studenoga 2018. godine 
dom druge nadležnosti AZTN-a utvrđeno je da je puna primjena ZNTP-a počela sredinom 2018. te se za analizu provedbe iz druge nadležnosti AZTN-a koriste podaci iz 2019. U području zaštite tržišnog natjecanja u 2018. okončano je 18 postupaka ocjena dopuštenosti koncentracija, pet postupaka ocjene zabranjenih sporazuma i 17 postupaka iz utvrđivanja zlouporaba. Prosječna je duljina postupaka iz ocjena koncentracija 73 dana, utvrđivanja zlouporaba vladajućeg položaja 433 dana te u zabranjenim sporazumima 90 dana. AZTN je 2018. proveo i okončao četiri sektorska istraživanja: istraživanje tržišta distributivne trgovine na malo i veliko mješovitom robom, pretežno hranom, pićima i higijenskim proizvodima za domaćinstvo u Republici Hrvatskoj 2017., istraživanje tržišta tiska u Republici Hrvatskoj u 2017., istraživanje tržišta osiguranja u Republici Hrvatskoj u 2017., istraživanje tržišta mlijeka i mliječnih proizvoda u Republici Hrvatskoj u 2017. Istraživanja su provedena radi boljeg razumijevanja strukture pojedinih mjerodavnih tržišta i analize postupanja sudionika na tim tržištima. Analize tržišta ili pojedine prakse na tržištu uključuju i analizu propisa koji se odnose na pojedino tržište te često otkrivaju nepravilnosti koje nisu u skladu s propisima o tržišnom natjecanju. Dobiveni rezultati mogu predstavljati osnovu za pokretanje postupaka protiv poduzetnika ili potrebu za dodatnom regulacijom na određenom tržištu.

U vezi s provođenjem propisa iz druge nadležnosti AZTN-a, utvrđivanjem nepoštenih trgovačkih praksi u lancu opskrbe hranom učinjen je znatan pomak. „Od početka primjene ZNTP-a do kraja 2019. okončano je 144 predmeta, od toga je sedam upravnih postupaka. AZTN, počevši od lipnja 2018., po službenoj dužnosti pokrenuo je veliki broj upravnih postupaka, u kojima je utvrđivao iskorištavanje značajne pregovaračke snage nametanjem nepoštenih trgovačkih praksi u lancu opskrbe hranom od strane velikog broja trgovaca, otkupljivača i prerađivača. U tim je postupcima AZTN ispitivao sve elemente koji se odnose na sadržaj i realizaciju ugovornih, odnosno poslovnih odnosa. Prosječna duljina trajanja upravnih postupaka je 311 dana. Ukupno je izrečeno upravno-kaznenih mjera u iznosu od gotovo 3,5 milijuna kuna." ${ }^{10}$

je istekao mandat troje članova Vijeća, a Hrvatski sabor je nove članove imenovao tek 25. siječnja 2019. godine."

10 Godišnje izvješće o radu Agencije za zaštitu tržišnog natjecanja za 2018. godinu, str. 8, dostupno na http://www.aztn.hr/ea/wp-content/uploads/2015/05/AZTN-Godisnje-izvjesce-za-2018.pdf. 
Tablica 6. Analiza provedbe ZZTN-a 2018.

\begin{tabular}{|c|c|}
\hline Ukupan broj svih predmeta & 688 \\
\hline \multicolumn{2}{|l|}{ Provedba - ocjena dopuštenosti koncentracija } \\
\hline broj okončanih upravnih postupaka iz ocjena koncentracija & 18 \\
\hline prosječan broj dana za rješavanje & 73 \\
\hline \multicolumn{2}{|l|}{ Provedba - ocjena zabranjenih sporazuma } \\
\hline broj okončanih upravnih postupaka & 9 \\
\hline nenajavljene pretrage & 0 \\
\hline prijave pokajnika & 0 \\
\hline izrečeno sankcija & 0 \\
\hline prosječan broj dana trajanja postupka & 90 \\
\hline \multicolumn{2}{|l|}{ Provedba - utvrđivanje zlouporaba vladajućeg položaja } \\
\hline broj okončanih upravnih postupaka & 17 \\
\hline izrečeno upravno-kaznenih mjera & 0 \\
\hline prosječan broj dana trajanja postupka & 433 \\
\hline
\end{tabular}

Izvor: Autor prema Godišnjem izvješću o radu AZTN-a u 2018. godini.

Tablica 7. Provedba ZTNP-a od početka primjene do kraja 2019.

\begin{tabular}{|l|l|l|}
\hline \multicolumn{2}{|l|}{ Ukupan broj svih predmeta } & 144 \\
\hline & broj okončanih upravnih postupaka & 7 \\
\hline & prosječan broj dana za rješavanje & 311 \\
\hline & izrečeno upravno-kaznenih mjera & $3.499 .500,00$ kuna \\
\hline
\end{tabular}

Izvor: Autor prema Godišnjem izvješću o radu AZTN-a u 2019. godini.

Promicanje svijesti o tržišnom natjecanju i nepoštenim trgovačkim praksama. AZTN je 2018. donio velik broj mišljenja na prijedloge propisa i dao očitovanja na upite građana i poduzetnika. AZTN takva stručna mišljenja donosi na zahtjev Hrvatskog sabora, Vlade RH, središnjih tijela državne uprave, pravnih osoba s javnim ovlastima u skladu s posebnim zakonom i tijela jedinica lokalne i područne (regionalne) samouprave, ali i u drugim slučajevima za koje smatra da je donošenje mišljenja važno za zaštitu tržišnog natjecanja. U 2018. AZTN je donio 32 mišljenja o propisima (zakonskim i podzakonskim aktima), četiri stručna mišljenja u sektoru elek- 
troničkih komunikacija te je dao 50 očitovanja na upite ostalih pravnih osoba, građana i poduzetnika. ${ }^{11}$

Velik opseg poslovanja odlazi i na suradnju s drugim agencijama u članicama Europske unije putem ECN-a. Važno je naglasiti da je uspješno završeno sudjelovanje AZTN-a u procesu pregovora oko ECN+ direktive u okviru radnih tijela Vijeća EU-a, koja je i prihvaćena početkom 2019. godine. Također, nastavljen je rad u Odboru za tržišno natjecanje OECDa i u Međunarodnoj mreži tijela za zaštitu tržišnog natjecanja. Počela je i provedba projekta EU-a Twinning Light u Crnoj Gori.

\subsection{Komisija za tržište i tržišno natjecanje, Španjolska (model C)}

Za model C specifična je multisektorska regulacija paralelna sa zaštitom tržišnog natjecanja, što znači da tijela u modelu $\mathrm{C}$ istodobno obavljaju poslove regulacije određenih dijelova gospodarstava i nadziru provedbu propisa iz tržišnog natjecanja. Prema podacima iz Tablice 1. u Europi je model C zastupljen u osam zemalja, i to u Estoniji, Lihtenštajnu, Malti, Nizozemskoj, Poljskoj, Rusiji, Španjolskoj i Ujedinjenom Kraljevstvu.

Kao primjer modela $\mathrm{C}$ analizira se rad španjolskog tijela za tržište i konkurenciju naziva La Comisión Nacional de los Mercados y la Competencia (dalje u tekstu: CNMC) u 2018. godini. CNMC je sadašnji oblik organizacije ostvario znatnim organizacijskim promjenama 2013. U lipnju 2013. španjolski parlament izglasao je Zakon 3/2013 kojim se osniva novo tijelo zaduženo za provedbu propisa o tržišnom natjecanju i regulaciju određenih sektora tržišta. CNMC je nastao tako da su se spojila četiri sektorska regulatora: Nacionalna komisija za energetiku (dalje u tekstu: CNE), Komisija za telekomunikacije (dalje u tekstu: CNT), Odbor za regulaciju željeznica (dalje u tekstu: CRF) i Nacionalna komisija za regulaciju poštanskih usluga (dalje u tekstu: CNSP) s Agencijom za konkurenciju Španjolske (dalje u tekstu: CNC). Tako se u nadležnost CNMC-a stavlja regulacija energetike, telekomunikacija, željeznica, poštanskih usluga, audiovizualnih usluga i zračnog prometa s jedne strane te zaštita tržišnog natjecanja s druge strane.

11 I Godišnje izvješće o radu Agencije za zaštitu tržišnog natjecanja za 2018. godinu, str. 13, dostupno na http://www.aztn.hr/ea/wp-content/uploads/2015/05/AZTN-Godisnje-izvjesce-za-2018.pdf. 
5. Organizacijska struktura CNMC-a. Glavne organizacijske jedinice CNMC-a:

- Vijeće CNMC-a u dvije komore: Komora za tržišno natjecanje i Regulacijska komora

- Tajništvo Vijeća CNMC-a s pripadajućim Odjelom za pravna pitanja

- Glavno tajništvo

- Odjel za promicanje tržišnog natjecanja

- Odjel za unutarnju kontrolu

- Uprava za tržišno natjecanje

- Uprava za energetiku

- Uprava za telekomunikacije i audiovizualne usluge

- Uprava za transport i poštanske usluge.

CNMC-om upravlja Vijeće CNMC-a koje se sastoji od deset članova predsjednika, zamjenika predsjednika i osam članova. Članove imenuje španjolska vlada na prijedlog ministarstva za gospodarstvo uz mogućnost stopiranja od španjolskog parlamenta. Imenuju se na šest godina bez mogućnosti ponovnog imenovanja. Najčešće se svake dvije godine odvija djelomično imenovanje tako da mandat članova nije vezan jedan za drugog. Vijeće CNMC-a djeluje u dvije skupine ili formacije, jedna je vezana za tržišno natjecanje, a druga za regulaciju. Kao administrativno-tehnička potpora u sklopu Vijeća CNMC-a osnovano je Tajništvo Vijeća CNMC-a u kojem su Ured potpredsjednika i Odjel za pravna pitanja. Sve odluke donose se većinom glasova uz presudni glas predsjednika Vijeća CNMCa. U operativnom dijelu, stručna služba podijeljena je na četiri glavne uprave. Svaka je odgovorna za svoje područje. Tako su osnovane Uprava za tržišno natjecanje, Uprava za energetiku, Uprava za telekomunikacije i audiovizualne usluge i Uprava za transport i poštanske usluge. Unutar svake uprave osnovani su odjeli za svaku vrstu djelatnosti koju nadziru. Osim navedenih odjela, osnovane su i ostale ustrojstvene jedinice s posebnim zadacima. Tako postoji Jedinica za promicanje tržišnog natjecanja, Odjel za menadžment, Glavno tajništvo i Ured predsjednika. ${ }^{12}$

6. Podaci o zaposlenima. Podaci iz Tablice 8. prikazuju da je 2018. u CNMC-u bilo zaposleno 186 zaposlenika, od toga 134 isključivo na poslovima tržišnog natjecanja. Ostali su zaposlenici administrativno osoblje.

12 Organizacijsku strukturu CNMC-a vidjeti na: https://www.cnmc.es/sobre-la-cnmc/organigrama. 
Odnos žena naspram muškaraca ide u prilog ženskom spolu sa 62 \% zastupljenosti. Također je visok postotak visokoobrazovanih (90 \%), što uključuje najviše pravnika i ekonomista. Točna podjela po sektorima nije moguća zbog stalne cirkulacije zaposlenika iz sektora u sektor po potrebi posla. Od ukupnog proračuna od oko 15 milijuna eura, $75 \%$ odlazi na plaće, što iznosi oko 11,25 milijuna eura.

Tablica 8. Podaci o zaposlenima u 2018. godini u CNMC-u

\begin{tabular}{|c|c|}
\hline ukupan broj zaposlenih & 186 \\
\hline ukupan broj novozaposlenih & 29 \\
\hline ukupan broj odljeva zaposlenih & 14 \\
\hline broj zaposlenih na poslovima tržišnog natjecanja & 134 \\
\hline odnos broja žena naspram broja muškaraca & $62 \% / 38 \%$ \\
\hline prosječna starost zaposlenika & 44 godine \\
\hline postotak visokoobrazovanih & $90 \%$ \\
\hline postotak pravnika & $48 \%$ \\
\hline postotak ekonomista & $42 \%$ \\
\hline ukupan broj zaposlenika sa završenim stupnjem doktora znanosti & 7 \\
\hline broj zaposlenika koji rade na ocjeni koncentracija & neodređeno \\
\hline broj zaposlenika koji rade na utvrđivanju zlouporaba & neodređeno \\
\hline broj zaposlenika koji rade na utvrđivanju zabranjenih sporazuma & neodređeno \\
\hline ukupan proračun & 15 milijuna eura \\
\hline izdvajanja za plaće & $75 \%$ \\
\hline
\end{tabular}

Izvor: Autor prema GCR-u (2019, str. 173).

Provedba propisa. U pogledu ocjena dopuštenosti koncentracija, CNMC je 2018. zatvorio 83 predmeta s prosječnim trajanjem postupka od 240 dana. U dijelu zabranjenih sporazuma, odnosno ocjene sporazuma zatvoreno je osam predmeta i izrečeno je 115 milijuna eura kazni. Provedene su četiri nenajavljene pretrage te je prosječno trajanje postupka oko 630 dana. Podatak o broju prijavljenih pokajnika u pokajničkom programu smatra se tajnim jer su neki postupci još uvijek u tijeku. Sveukupno je zatvoreno sedam predmeta u dijelu utvrđivanja zlouporaba vladajućeg položaja od kojih je samo jedan predmet zatvoren prihvaćanjem mjera koje se nameću poduzetniku s ciljem otklanjanja negativnih učinaka na tržišno natjecanje, u ostalim predmetima odbačene su inicijative. Prosječno je 
trajanje postupka 630 dana. Jedan je od važnih predmeta izvan tržišnog natjecanja postupak protiv četiriju najvećih španjolskih banaka (Santander, Sabadell, BBVA i CaixaBank) radi koordiniranja kamatnih stopa kod sindikalnih kredita koje su na kraju kažnjene s 91 milijunom eura. Ukupno je CNMC 2018. izrekao 215 milijuna eura kazni. Provedena su tri istraživanja tržišta: istraživanje kratkotrajnog najma smještaja, istraživanje kontrole zračnog prometa i natjecateljski duh uvođenjem novih tehnologija u financijski sektor.

Što se tiče sudskog nadzora nad donesenim odlukama, pokrenuta je 71 tužba na 30 odluka CNMC-a. Upravni sudovi presudili su u povodu 16 tužbi u korist CNMC-a te u 27 tužbi protiv odluka CNMC-a. Vrhovni sud potvrdio je odluke u 20 tužbi i ukinuo odluke u povodu osam tužbi. Najčešći je razlog ukidanja postupovne prirode.

Tablica 9. Provedba u CNMC-u 2018.

\begin{tabular}{|l|l|l|}
\hline \multicolumn{2}{|l|}{ Provedba - ocjena dopuštenosti koncentracija } & \\
\hline & broj zatvorenih predmeta & 83 \\
\hline & prosječan broj dana za rješavanje & 240 \\
\hline Provedba - ocjena zabranjenih sporazuma & \\
\hline & broj zatvorenih predmeta & 8 \\
\hline & nenajavljene pretrage & 7 \\
\hline & prijave pokajnika & nedostupno \\
\hline & izrečeno sankcija & 115 milijuna eura \\
\hline Provedba - utvrđivanje zlouporaba vladajućeg položaja & 630 \\
\hline & broj zatvorenih predmeta & \multicolumn{2}{l|}{} \\
\hline & izrečeno sankcija & 7 \\
\hline & prosječan broj dana trajanja postupka & 0 \\
\hline Provedba - regulacija ostalih sektora & 630 \\
\hline & broj zatvorenih predmeta u ostalim nadležnostima & 4 \\
\hline & izrečeno sankcija & 100 milijuna eura \\
\hline
\end{tabular}

Izvor: Autor prema GCR-u (2019, str. 173-174).

7. Promicanje svijesti o tržišnom natjecanju. Bitan uspjeh u dijelu promicanja tržišnog natjecanja ostvaren je u sektorima kratkotrajnog najma smješta- 
ja, uslugama prijevoza taksijem, regulaciji profesija, državnim potporama u gradskom prijevozu i uslugama međugradskog prijevoza. Provedenim istraživanjima i stalnim radionicama s poduzetnicima iz navedenog sektora teži se uspostavi natjecateljskog tržišta. U obavljanju poslova iz svoje nadležnosti CNMC i dalje najveće napore usmjerava na zaštitu tržišnog natjecanja uz ostale regulacijske nadležnosti. Izdano je 19 regulacijskih izvješća o pojedinim sektorima gospodarstva, dano je 13 očitovanja na upite građana i izdano osam mišljenja na prijedloge propisa (GCR, 2019, str. 174).

\subsection{Evaluacija provedenog istraživanja}

Provedeno istraživanje organizacijskih aspekata tijela za tržišno natjecanje pokazalo je da je regulacija tržišnog natjecanja u europskim zemljama uređena trima osnovnim modelima. Sa svrhom nalaženja odgovora na pitanje koji je model najuspješniji, usporedit će se dobiveni rezultati iz istraživanja. Kriteriji prema kojima se uspoređuju modeli jesu stupanj autonomije tijela upravljanja, profesionalizacija zaposlenih i trajanje provedenih postupaka.

Autonomija tijela upravlianja. Tijelo je upravljanja u AZTN-u Vijeće AZTNa, u AdC-u Vijeće AdC-a te u CNMC-u Vijeće CNMC-a. Prva je razlika tih tijela upravljanja način odabira odnosno imenovanja njihovih članova. U AZTN-u i AdC-u članove vijeća imenuje Hrvatski sabor odnosno parlament na prijedlog vlade. U Španjolskoj članove Vijeća CNMC-a imenuje vlada na prijedlog ministarstva za gospodarstvo. Parlamentu je ostavljena mogućnost veta kroz rad Odbora za ekonomska pitanja i digitalizaciju. Jedna je od temeljnih karakteristika nezavisnih regulacijskih agencija autonomija u odnosu na izvršnu vlast koja se ostvaruje na način da vodstvo imenuje parlament.

Podaci iz Tablice 10. idu u prilog tvrdnji da je potrebna dodatna autonomija u načinu imenovanja članova tijela upravljanja. Ni kod jednog tijela ne provodi se javni natječaj za popunjavanje radnih mjesta za članove vijeća. Nešto je ipak lošiji slučaj kod imenovanja članova Vijeća CNMC-a koji su direktno podložni političkim promjenama, dok je u ostalim dvama promatranim tijelima politički utjecaj smanjen odabirom u parlamentima. Prema toj karakteristici u prednosti su model A i model B naspram modela C. 
Tablica 10. Usporedba načina imenovanja članova tijela upravljanja

\begin{tabular}{|c|c|c|}
\hline AZTN & AdC & CNMC \\
\hline zakonodavac & zakonodavac & vlada \\
\hline
\end{tabular}

Izvor: Autor prema podacima sa službenih internetskih stranica.

Profesionalizacija zaposlenika. Profesionalizacija zaposlenika instrument je kojim se nastoji odvojiti upravno postupanje od političkog utjecaja. „Profesionalizacija se ostvaruje primjenom merit sustava pri odabiru, zapošljavanju i postavljanju kandidata na radna mjesta i položaje u javnoj upravi prema kriterijima stručnosti i sposobnosti." (Koprić et al., 2014, str. 139). Usporedba profesionalizacije zaposlenika zasniva se na podacima o postotku visokoobrazovanih, broju pravnika i ekonomista te broju zaposlenika sa znanstvenim stupnjem doktora znanosti u svakom od predmetna tri modela. Odlika su svih istraživanih tijela visokoobrazovani zaposlenici koji su u pravilu pravnici i ekonomisti. Prednost je ostalih agencija u odnosu na AZTN veći broj doktora znanosti. Valja naglasiti da se kod svih tijela provodi javni natječaj kod zapošljavanja u stručnim službama. Kod tog je kriterija uspješnost svih modela jednaka jer je podjednak postotak visokoobrazovanih u svim promatranim tijelima.

Tablica 11. Usporedba zaposlenih prema kriteriju obrazovanja (usporedba podataka iz Tablice 3., Tablice 5. i Tablice 8.)

\begin{tabular}{|l|c|c|c|}
\hline & AZTN & AdC & CNMC \\
\hline postotak visokoobrazovanih & $91 \%$ & $90 \%$ & $90 \%$ \\
\hline postotak pravnika & $42 \%$ & $52 \%$ & $48 \%$ \\
\hline postotak ekonomista & $28 \%$ & $38 \%$ & $42 \%$ \\
\hline $\begin{array}{l}\text { broj zaposlenih radnika sa stupnjem } \\
\text { doktora znanosti }\end{array}$ & 1 & 8 & 7 \\
\hline
\end{tabular}

Izvor: Autor.

8. Trajanje postupka. „Važnost upravljanja učinkovitošću je veća što je javna uprava pod većim pritiskom da se opravda i legitimira u društvu." (Koprić et al., 2014, str. 132). Jedan od načina mjerenja produktivnosti broj je riješenih upravnih postupaka. S obzirom na to da je broj riješenih upravnih predmeta u području tržišnog natjecanja vezan za okolišne čimbenike, osobito gospodarske aktivnosti, kao posljednji kriterij prema kojem 
se uspoređuju ostvareni rezultati uzima se trajanje provedenih upravnih postupka. Postupci zaštite tržišnog natjecanja u članicama Europske unije temelje se na odredbama propisanim u člancima 101. i 102. UFEU-a, pa su ih članice dužne transponirati u nacionalno zakonodavstvo. Tako su postupci utvrđivanja zabranjenih sporazuma, utvrđivanja zlouporaba i ocjena koncentracija homogeni u AZTN-u, AdC-u i CNMC-u uz iznimku visine pragova prijave na ocjenu koncentracija. Svi navedeni postupci iznimno su dugotrajni jer zahtijevaju specijalizirano znanje o određenim sektorima gospodarstva, donošenju odluka gotovo uvijek prethodi istraživanje određenoga mjerodavnog tržišta. Duljina i kvaliteta provedenih postupaka temelj je analize učinkovitosti i djelotvornosti organizacije.

Tablica 12. Usporedba provedbe propisa prema trajanju postupka u 2018. godini (usporedba podataka iz Tablice 4., Tablice 6., Tablice 7. i Tablice 9.)

\begin{tabular}{|l|c|c|c|}
\hline & AZTN & AdC & CNMC \\
\hline $\begin{array}{l}\text { prosječno trajanje postupaka ocjena } \\
\text { koncentracija u danima }\end{array}$ & 73 & 199 & 240 \\
\hline $\begin{array}{l}\text { prosječno trajanje postupaka ocjena } \\
\text { zabranjenih sporazuma u danima }\end{array}$ & 90 & 675 & 630 \\
\hline $\begin{array}{l}\text { prosječno trajanje postupaka utvrđiva- } \\
\text { nja zlouporaba u danima }\end{array}$ & 433 & 1.298 & 630 \\
\hline $\begin{array}{l}\text { prosječno trajanje postupaka utvrđi- } \\
\text { vanja nepoštenih trgovačkih praksi u } \\
\text { danima }\end{array}$ & 311 & - & $\begin{array}{c}\text { nedostupni } \\
\text { podaci }\end{array}$ \\
\hline
\end{tabular}

Izvor: Autor.

Unatoč homogenosti postupaka provedeno istraživanje upućuje na to da se neka tijela uzeta kao primjeri određenih organizacijskih modela bolje snalaze u provedbi od drugih. Podaci iz Tablice 12. pokazuju da je velika razlika u trajanju postupaka u AZTN-u s jedne te AdC-u i CNMC-u s druge strane. Postupak ocjene dopuštenosti koncentracija u 2018. u AZTN-u trajao je prosječno 73 dana, dok je u AdC-u trajao 199 te u CNMC-u 240 dana. Ocjena zabranjenih sporazuma u AZTN-u trajala je 90 dana, što je znatno kraće u odnosu na AdC ( 675 dana) i CNMC (630 dana). Također, velika je razlika u trajanju postupaka utvrđivanja zlouporaba u odnosu AZTN-a (433 dana) prema AdC-u (1.298 dana) i CNMC-u (630 dana). Prema tome kriteriju, model B mnogo je produktivniji i učinkovitiji. 


\section{Preporuke za Republiku Hrvatsku}

Popović (2016, str. 19-20) ističe „funkcionalnu povezanost sektorskih regulatora i tijela za zaštitu tržišnog natjecanja te ostavlja po strani uobičajene podjele na više regulatora kao upravno-administrativni atavizam, koji je skuplji i pritom povećava rizik nekoherentnog pristupa politici tržišnog natjecanja s obzirom na različite tržišne regulatore, koji odlučuju o pravnim i ekonomskim pitanjima koja su srodna i obuhvaćaju sve aspekte prava tržišnog natjecanja“. Kao primjere uzima spajanja agencija u Nizozemskoj i Španjolskoj koja su za cilj imala smanjenje upravnog aparata s ciljem ,štednje, ali i jačanje učinkovitosti nadzora tržišta i provedbe odgovarajućih politika" (ibid.). Navedeno koristi za dokazivanje tvrdnje o potrebi spajanja AZTN-a i HAKOM-a te osnivanje jedinstvenog tijela koje će odlučivati o poslovima zaštite tržišnog natjecanja i regulacije mrežnih djelatnosti - Vijeće za zaštitu tržišnog natjecanja i regulaciju mrežnih djelatnosti (dalje u tekstu: VZTN-REG) (Popović, 2014, str. 223). Turudić (2014, str. 18-20) ističe potrebu organizacijskih reformi u regulaciji mrežnih djelatnosti u RH. Kao primjer uzima njemačku Saveznu agenciju za električnu energiju, plin, elektroničke komunikacije, poštu i željeznice, službenog naziva Bundesnetzagentur für Elektrizität, Gas, Telekommunikation, Post und Eisenbahnen (dalje u tekstu: BNETZA). Predlaže osnivanje regulacijske agencije za mrežne industrije koja bi imala zasebne odjele za poštu, elektroničke komunikacije i željezničke usluge. Osnivanje takve agencije rezultiralo bi spajanjem HAKOM-a i HERA-e.

$\mathrm{S}$ obzirom na rezultate istraživanja provedenog $\mathrm{u}$ ovom radu, može se zaključiti da u Hrvatskoj nisu potrebna spajanja sektorskih regulatora s AZTN-om. Također, odvojenim pristupom regulaciji tržišnog natjecanja ex ante (HAKOM) i ex post (AZTN) daje se veća pravna sigurnost, a sve kako bi se osiguralo poticanje tržišnog natjecanja, zaštita prava krajnjih korisnika te otvorenost i konkurentnost u korist građana i poduzetnika. Usporedbom podataka pojedinih primjera zaključeno je da trenutačno u Hrvatskoj nisu potrebne organizacijske promjene u regulaciji i provedbi propisa o tržišnom natjecanju te da je trenutačni model optimalan.

Daljnji razvoj AZTN-a, ali i ostalih nezavisnih regulacijskih agencija $\mathrm{u}$ Hrvatskoj ne temelji se na spajanju, ukidanju ili nekoj drugoj organizacijskoj promjeni. Daljnji razvoj temelji se na jačanju autonomije regulacijskih agencija s jedne strane te stalnom, funkcionirajućem nadzoru s druge strane. 
Direktiva (EU) 2019/1 ${ }^{13}$ Europskog parlamenta i Vijeća traži ostvarenje sljedećih ciljeva radi jačanja neovisnosti nacionalnih tijela za zaštitu tržišnog natjecanja:

1. osigurati svim nacionalnim tijelima za tržišno natjecanje učinkovite instrumente za provođenje postupka (istrage) i donošenje odluka

2. osigurati izricanje odvraćajućih kazni

3. zajamčiti svim nacionalnim tijelima za tržišno natjecanje dobro osmišljene programe oslobođenja od kazne ili njezina umanjenja da bi se potaknulo podnošenje zahtjeva za oslobođenje od kazne ili njezino umanjenje u više jurisdikcija

4. osigurati nacionalnim tijelima za tržišno natjecanje dovoljno financijskih i ljudskih resursa da bi mogla neovisno provoditi pravila EU-a o tržišnom natjecanju.

Prvi je prijedlog za jačanje autonomije promjena načina odabira članova tijela upravljanja. Članove Vijeća AZTN-a trenutačno imenuje Hrvatski sabor na prijedlog Vlade RH. Predlaže se da članove Vijeća AZTN-a bira Hrvatski sabor, ali na temelju javnog natječaja koji će provesti stručna služba Hrvatskog sabora. Takvim načinom odabira članova smanjio bi se politički utjecaj izvršne vlasti. Uvjeti vezani za radni staž, obrazovanje i nekažnjavanost ostali bi i dalje.

Sljedeći prijedlog za jačanje autonomije odnosi se na zapošljavanje u stručnim službama. AZTN pri svakom zapošljavanju traži dopuštenje Ministarstva gospodarstva i obveznik je odluke Vlade „dva za jedan“. ${ }^{14} \mathrm{Ta}$ se odredba ne bi trebala odnositi na zapošljavanje u regulacijskim agencijama jer je očito riječ o upletanju izvršne vlasti u upravljanje ljudskim potencijalima.

U AZTN-u je 2018. zaposleno novih osam zaposlenika. Primljeni su radi nove nadležnosti u provedbi ZNTP-a. Svi su zaposleni na izvanredan način na srednje i visoke pozicije u hijerarhijskoj strukturi AZTN-a. Naime, AZTN od 2014., kada je zaposlio tri pripravnika, nije nikoga zaposlio na redovit način. Dakle, predlaže se zapošljavanje pripravnika (vježbenika) pravnika koje treba uvoditi u posao s ciljem da javna služba postane ka-

13 Direktiva (EU) 2019/1 Europskog parlamenta i Vijeća od 11. prosinca 2018. o ovlašćivanju tijela država članica nadležnih za tržišno natjecanje za učinkovitiju provedbu pravila o tržišnom natjecanju i osiguravanju pravilnog funkcioniranja unutarnjeg tržišta (Tekst značajan za EGP.) SL L 11, 14. siječnja 2019. godine, str. 3-33.

14 Odluka Vlade RH o zabrani novog zapošljavanja službenika i namještenika u javnim službama, NN 70/16, 50/17, 37/18, 71/18, 91/18 i 33/20. 
rijera i trajno zanimanje. Takav način ne samo da motivira već postojeće zaposlenike, nego doprinosi „jačanju kolektiva“ radi „nove energije“ koju mladi bez iskustva donose u organizacije. Time se rješava i pitanje zapošljavanja mladih bez iskustva.

\section{Zaključak}

U ovom radu prikazana je problematika agencija općenito te je dana analiza organizacijskih modela regulatora tržišnog natjecanja. Posljednjih godina agencije su pod velikim povećalom javnosti, a i velik je broj agencija ukinut. Nadalje su navedeni instrumenti odnosno načini kako se regulacija tržišnog natjecanja provodi. Istaknuta je regulacija propisima kao jedan od najvažnijih načina regulacije. Osim regulacije propisima, regulacija tržišnog natjecanja ostvaruje se i procesom europeizacije, radom međunarodnih tijela i samom provedbom propisa nacionalnih regulatora. Nacionalni regulatori tržišnog natjecanja najprije su tijela za tržišno natjecanje, tijela za zaštitu potrošača i sektorski regulatori. Svako od navedenih tijela na poseban način uređuje pitanje tržišnog natjecanja. Da bi se došlo do navedenog zaključka, najprije je provedeno istraživanje organizacijskih modela koji se pojavljuju u europskim državama. Utvrđena su tri organizacijska modela tijela za tržišno natjecanje u odnosu na njihove nadležnosti: model A u kojem je jedina nadležnost provedba zaštite tržišnog natjecanja, model B u kojem je tijelo za tržišno natjecanje nadležno, uz zaštitu tržišnog natjecanja, i za zaštitu potrošača i/ili ostale nadležnosti, dok je regulacija tržišta prepuštena sektorskim regulatorima te model $\mathrm{C}$ za koji je karakteristična nadležnost tijela za tržišno natjecanje u svim dijelovima tržišnog natjecanja, odnosno spojeni su sektorski regulatori s tijelima za tržišno natjecanje i tijelima za zaštitu potrošača. U nastavku istraživanja za primjere svakog od modela odabrana su određena tijela radi daljnje analize. Tako je za primjer modela $A$ analizirano ustrojstvo i djelokrug portugalskog AdC-a, za primjer modela B hrvatski AZTN te za primjer modela C španjolski CNMC. U istraživanju su korišteni javno dostupni podaci sa službenih stranica navedenih tijela, iz godišnjih izvješća o radu te podaci iz časopisa GCR (2019). Analizirana su obilježja ustrojstva i djelokruga, upravljanja ljudskim potencijalima, provedba propisa i promicanje tržišnog natjecanja. Utvrđen je nerazmjer u trajanju postupaka kao temelju produktivnosti i učinkovitosti upravne organizacije. U AZTN-u s manjim brojem zaposlenih i manjim financijskim sredstvima mnogo kraće traju svi upravni postupci u odnosu na AdC i CNMC. 
Sljedeća istraživanja iz područja regulacijskih agencija trebala bi fokus usmjeriti na poticanje suradnje i koordinacije između regulacijskih agencija i ostalih tijela državne uprave u Hrvatskoj te pronalazak zajedničkih rješenja u vremenima koja dolaze.

\section{Popis literature}

Bajakić, I. (2010). Razvoj i učinci regulatornih agencija u SAD-u: Uspješan model za Europu? Zbornik Pravnog fakulteta u Zagrebu, 60(2), 495-526.

Butorac Malnar, V., Pecotić Kaufman, J., \& Petrović, S. (2013). Pravo tržišnog natjecanja. Zagreb, Hrvatska: Sveučilište u Zagrebu, Pravni fakultet.

Cerovac, M. (2009). Novi Zakon o zaštiti tržišnog natjecanja: značajne novine. Hrvatska pravna revija, 10/2009, Inženjerski biro, Zagreb. Dostupno na http:// www.aztn.hr/uploads/documents/clanci/Novi_ZZTN_znacajne_novine.pdf.

Global Competition Review, (GCR 2019). Rating enforcement, The annual ratings of the worlds leading competition authorities, Law Business Research.

Jenny, F. (2016). The institutional design of competition authorities: Debates and trends. Dostupno na https://ssrn.com/abstract=2894893, doi https://doi. org/10.2139/ssrn.2894893.

Koprić, I. (2013). Razvoj i problemi agencijskog modela s posebnim osvrtom na nezavisne regulatore. U: I. Koprić, A. Musa \& V. Đulabić (Ur.), Agencije u Hrvatskoj: regulacija i privatizacija javnih službi na državnoj, lokalnoj $i$ regionalnoj razini. Zagreb, Hrvatska: Institut za javnu upravu.

Koprić, I., Marčetić, G., Musa, A., Đulabić, V., \& Lalić Novak, G. (2014). Upravna znanost - javna uprava u suvremenom europskom kontekstu. Zagreb, Hrvatska: Sveučilište u Zagrebu, Pravni fakultet, Studijski centar za javnu upravu i javne financije, Suvremena javna uprava.

Manojlović, R. (2010). Danski model novog javnog menadžmenta - može li poslužiti kao uzor Hrvatskoj? Hrvatska i komparativna javna uprava, 10(4), 961-996.

Mecanović, I., \& Novosel, Z. (2012). Državne regulatorne agencije u funkciji regulacije tržišta i tržišne konkurencije. Pravni vjesnik, 28(3-4), 63-87.

Musa, A. (2012). Agencifikacija kao nova i dodatna centralizacija - hoće li se Hrvatska ikada moći decentralizirati. Hrvatska $i$ komparativna javna uprava, 12(4), 1197-1124.

Musa, A. (2014). Agencijski model javne uprave. Zagreb, Hrvatska: Sveučilište u Zagrebu, Pravni fakultet, Studijski centar za javnu upravu i javne financije, Suvremena javna uprava.

Musa, A., Banić, S., Đurman, P., Džinić, J., Giljević, T., Koprić, I., Lalić Novak, G., \& Zelenika, B. (2020). Regulacijski menadžment: nastavni materijali 2020. Zagreb, Hrvatska: Pravni fakultet. 
Ottow, A. (2015). Market and competition authorities, Good agency principles. Oxford, UK: Oxford University Press, https://doi.org/10.1093/acprof:o so/9780198733041.001.0001.

Popović, N. (2014). Tržišni regulatori: Quo vaditis? Zagreb, Hrvatska: Pravni fakultet.

Popović, N. (2016). Neovisni regulatori: kako osigurati učinkovitost i odgovornost? Forum za javnu upravu. Javne agencije: u potrazi za reformom. Zagreb, Hrvatska: Friedrich-Ebert-Stiftung, ured za Hrvatsku, Institut za javnu upravu.

Staničić, F. (2017). Kontrola rada regulatornih agencija u Republici Hrvatskoj. Forum za javnu upravu: Javne agencije: u potrazi za reformom. Zagreb, Hrvatska: Friedrich-Ebert-Stiftung, ured za Hrvatsku, Institut za javnu upravu.

Turudić, M. (2014). Spajanje regulatornih agencija za mrežne industrije - korak u pravom smjeru? Informator: instruktivno-informativni list za ekonomska $i$ pravna pitanja, 2014(6253), 18-20.

\section{Službeni dokumenti i izvješća}

Godišnje izvješće o radu Agencije za zaštitu tržišnog natjecanja za 2018. godinu. Dostupno na http://www.aztn.hr/ea/wp-content/uploads/2015/05/AZTN-Godisnje-izvjesce-za-2018.pdf.

Godišnje izvješće o radu Agencije za zaštitu tržišnog natjecanja za 2019. godinu.

\section{Pravni propisi}

Zakon o zabrani nepoštenih trgovačkih praksi u lancu opskrbe hranom, NN $117 / 17$.

Zakon o zaštiti tržišnog natjecanja, NN 79/09, 80/13.

Odluka Vlade RH o zabrani novog zapošljavanja službenika i namještenika u javnim službama, NN 70/16, 50/17, 37/18, 71/18, 91/18 i 33/20.

\section{Internetske stranice}

www.aztn.hr

www.concorrencia.pt

www.cnmc.es 


\section{ORGANISATIONAL ASPECTS OF THE COMPETITION REGULATORS}

\section{Summary}

The main task of the contemporary state is to ensure the functioning of the market and to pursue the public interest through independent regulation, which requires the establishment of regulatory agencies. Over time, negative and somewhat mystical bias towards these agencies has occurred in the public. The public administration reform is an integral part of the political programme of any political actor in the Republic of Croatia and regulatory agencies are one of its main targets. A desktop survey that is a base of this paper included individual competition agencies representing one of the three main European organisational models for competition agencies and investigated their characteristics with respect to organization, personnel aspects, and enforcement. The Portuguese competition authority has been taken as the representative of Model $A$ - the authority with only one jurisdiction - enforcement of competition rules. The Croatian competition authority was taken as the example of Model B - the authority with dual competence - competition and unfair trading practices. Finally, Model C was analysed on the example of the Spanish competition authority that is responsible for the enforcement of competition rules but at the same time for ex-ante regulation in individual sectors. The results of the survey are expected to provide solutions for the best organizational model, and consequently give further evidence of whether an organizational reform of the Croatian Competition Agency would be necessary in the Republic of Croatia.

Keywords: regulation, regulatory authorities, organizational changes, organizational models, competition 